\title{
Accelerated glacier shrinkage in the Ak-Shyirak massif, Inner Tien Shan, during 2003-2013
}

\author{
Dmitry Petrakov ${ }^{1}$, Alyona Shpuntova ${ }^{1}$, Alexandr Aleinikov ${ }^{2}$, Andreas Kääb ${ }^{3}$, Stanislav Kutuzov ${ }^{4}$, \\ Ivan Lavrentiev ${ }^{4}$, Markus Stoffel ${ }^{5,6}$, Olga Tutubalina $^{1}$, Ryskul Usubaliev $^{7}$ \\ 1 - Faculty of Geography, M. V.Lomonosov Moscow State University, Moscow, Russia \\ 2 - ETC "ScanEX”, Moscow, Russia \\ 3 - Department of Geosciences, University of Oslo, Oslo, Norway \\ 4 - Laboratory of Glaciology, Institute of Geography, Russian Academy of Science, Moscow, Russia \\ 5 - Dendrolab.ch, Institute of Geological Sciences, University of Berne, Berne, Switzerland \\ 6 - Institute for Environmental Sciences, University of Geneva, Geneva, Switzerland \\ 7 - Central Asian Institute of Applied Geosciences (CAIAG), Bishkek, Kyrgyzstan
}

\section{Abstract}

The observed increase in summer temperatures and the related glacier downwasting has led to a noticeable decrease of frozen water resources in Central Asia, with possible future impacts on the economy of all downstream countries in the region. Glaciers in the Ak-Shyirak massif, located in the Inner Tien Shan, are not only affected by climate change, but also impacted by the open pit gold mining of the Kumtor Gold Company. In this study, glacier inventories referring to the years 2003 and 2013 were created for the Ak-Shyirak massif based on satellite imagery. The 193 glaciers had a total area of $351.2 \pm 5.6 \mathrm{~km}^{2}$ in 2013. Compared to 2003, the total glacier area decreased by 5.9+3.4\%. During 2003-2013, the shrinkage rate of Ak-Shyirak glaciers was twice than that in 1977-2003 and similar to shrinkage rates in Tien Shan frontier ranges. We assessed glacier volume in 2013 using volume-area (VA) scaling and GlabTop modelling approaches. Resulting values for the whole massif differ strongly, the VA scaling derived volume is $30.0 \div 26.4 \mathrm{~km}^{3}$ whereas the GlabTop derived volume accounts for $18.8 \div 13.2 \mathrm{~km}^{3}$. Ice losses obtained from both approaches were compared to geodetically-derived 
volume change. VA scaling underestimates ice losses between 1943 and 2003 whereas GlabTop reveals a good match for eight glaciers for the period 2003-2012. In comparison to radio-echo soundings from three glaciers, the GlabTop model reveals a systematic underestimation of glacier thickness with a mean deviation of 16\%. GlabTop tends to significantly underestimate ice thickness in accumulation areas, but tends to overestimate ice thickness in the lowermost parts of glacier snouts. Direct technogenic impact is responsible for about $7 \%$ of area and $5 \%$ of mass loss for glaciers in the Ak-Shyirak massif during 2003-2013. Therefore the increase of summer temperature seems to be the main driver of accelerated glacier shrinkage in the area.

Keywords: Tien Shan, the Ak-Shyirak massif, Remote sensing, GlabTop modelling, Glacier area change, Ice thickness, Glacier volume, Technogenic impact on glaciers

\section{Introduction}

Glaciers are recognized as key indicators for climate change (IPCC, 2007; Zemp, Van Woerden, 2008) and an important source of freshwater, especially in mountains surrounded by arid lowlands. In these regions, glacier meltwater has been described to play a crucial role for irrigation during the hot and dry seasons (Kazer et al., 2010; Sorg et al., 2012, 2014). In addition, any decrease of glacier runoff often also leads to economic losses and associated negative social consequences (e.g., Vergara et al., 2007).

In Central Asia, meltwater from glaciers provides an estimated $20-40 \%$ of total runoff during summers, both as seasonal contribution and from glacier imbalance, up to $70-80 \%$ in extremely hot and dry periods (IPCC, 2007; Kääb et al., 2015). Glacier meltwater runoff seems still not to diminish as the reduction of contributing glacier area to runoff is compensated by increased ablation so far (Aizen et al., 2007a). But further shrinkage of glaciated area is expected to lead to a decrease of river runoff during the summer period (Hagg et al., 2007, Sorg et al., 2012; 2014a). 
During recent decades glaciers in Tien Shan, surrounded by highly populated lowlands and piedmonts with extensive agricultural areas, were downwasting after a relatively stable period from the late 1950s to the early 1970s (Sorg et al., 2012). During 1960-2006, the glacier covered area reduced from 15,416 to $12,815 \mathrm{~km}^{2}$, volume over this period reduced by $219 \mathrm{~km}^{3}$ (Dyurgerov, 2010). As reported by Farinotti et al. (2015), during 1961-2012 glacier area losses in Tien Shan were $2960 \pm 1030 \mathrm{~km}^{2}$ whereas mass losses were $270 \pm 140$ Gt. Especially high rates of glacier shrinkage were observed at the outer ranges of the mountain system (Northern and Western Tien Shan; Aizen et al., 2006; 2007; Bolch, 2007; Narama et al., 2009; Niederer et al., 2007). In Inner, Central and Eastern Tien Shan, glacier recession rates were reported to be lower (Aizen et al., 2006; 2007, Hagg et al., 2012; Khromova et al., 2003; Kutuzov, Shahgedanova, 2009; Li et al., 2007; Narama et al., 2006, 2009; Osmonov et al., 2010; Sorg et al., 2012). Taking into account the expected glacier shrinkage, changes in glacier coverage in the Central Asian mountains should be monitored as recent climate change continues (Narama et al., 2009).

Existing assessments of glacier volume in Tien Shan vary from $1,048 \mathrm{~km}^{3}$ (Aizen et al., $2007 a$ ) to $1,369 \mathrm{~km}^{3}$ (Liu, Han, 1992) and $1,840 \mathrm{~km}^{3}$ (Aizen et al., 2008). Traditionally, glacier volume is assessed from volume-area (VA) scaling (e.g., Bahr, 1997; Erasov, 1968; Macheret et al., 1988; Macheret et al., 2013; Frey et al., 2014). In the Tien Shan region, this approach has, for instance, been used by Hagg et al. (2012) to assess glacier volumes in the Big Naryn catchment.

By contrast, the assessment of glacier thickness from surface topography (Haeberli, Hoelzle, 1995; Huss, Farinotti, 2012; Farinotti et al., 2009; Frey et al., 2014; Linsbauer et al., 2009; 2012; Paul, Linsbauer, 2012) allows to obtain data on ice thickness distribution and glacier bed geometry. So far, however, this approach has not been used for the Inner Tien Shan ranges despite its apparent and widespread potential (Frey et al., 2014). Direct information on the volume of Tien Shan glaciers is, by contrast, very limited. In the past, any decrease of glacier volume in Tien Shan was assessed mostly as surface lowering and extracted from multi-temporal 
remote sensing data in the Terskey AlaToo (Kutuzov, 2012), Ala-Archa (Kyrgyz range) and AkShyirak (Aizen et al., 2007) regions, in the Aksu-Tarim catchment (Pieczonka et al., 2013), and at Inylchek glacier (Shangguan et al., 2014). Future projections demonstrate significant volume losses in the $21^{\text {st }}$ century, (Radic et al., 2013). For future predictions of glacier areas and melt water yield, the current volume of glaciers is required (Hagg et al., 2012).

The challenges related to changing glacier areas and volumes is very important as water allocation is a highly sensitive topic in the Central Asian region (Lutz et al., 2013; Beniston et al., 2014; Sorg et al., 2014b). Donor countries of freshwater (Kyrgyzstan, Tajikistan) use water mostly for hydropower generation during winter, whereas the receiving downstream countries need water for irrigation during summers (China, Kazakhstan, Turkmenistan and Uzbekistan). In the latter three countries more than 20 million people depend on irrigated agriculture (Siegfried et al., 2012). Issues related to water availability and distribution have repeatedly led to political tensions, especially between Kyrgyzstan and Uzbekistan.

Typical conditions for such potential conflicts can be identified in the Ak-Shyirak massif, as it holds among the largest glacier-covered areas in the Inner Tien Shan (Oledeneniye Tien Shan'a, 1995). Meltwater from glaciers of the Ak-Shyirak feeds the Naryn (a tributary of Syrdarya) and Sary-Jaz (a tributary of Aksu and Tarim) rivers. Both rivers are transboundary, with the water from Syrdarya being used for irrigation in Uzbekistan and Kazakhstan and the waters from Sary-Jaz serving irrigation purposes in China. Within Kyrgyzstan, by contrast, the Naryn and Syrdarya rivers are used extensively for hydropower generation, and the country plans to establish further cascades of hydropower plants along the Naryn and Sary-Jaz rivers.

While the glaciers of the Ak-Shyirak region were apparently close to a stationary state during the mid-20 ${ }^{\text {th }}$ century (Bondarev, 1962), they started to exhibit signs of retreat in the 1970s and 1980s (Aizen et al., 2007b). As the Ak-Shyirak massif is among only a few sites in the world (Colgan, Arenson, 2013; Kronenberg, 2013) where glaciers are prone to direct technogenic impact - i.e. open pit excavation of glacier ice realized by the Kumtor Gold Company (KGC) for 
gold mining - the role of mining on the downwasting of Ak-Shyirak glaciers has repeatedly been subject of speculations.

The aim of this contribution therefore is to (i) create a contemporary glacier inventory for the Ak-Shyirak massif based on remote sensing data; (ii) estimate ice volume contained in the Ak-Shyirak area in 2013 using volume-area (VA) scaling and ice-thickness estimates; (iii) assess glacier changes between 2003 and 2013; as well as to (iv) quantify the impact of gold mining and climate change on glacier downwasting.

\section{Study area}

The Ak-Shyirak includes three subparallel ranges isolated from surrounding mountains (Fig. 1), the northern, medial and southern ranges. The northern range is in fact a continuation of the Kuiloo Range, with maximum elevations within Ak-Shyirak at $4946 \mathrm{~m}$ asl, the medial range represents a continuation of the Terekty Range (maximum altitude: $5126 \mathrm{~m}$ asl) and the southern range, being a continuation of the Ishigart Range, culminates at $4983 \mathrm{~m}$ asl. The highest point of the Ak-Shyirak region has an elevation of $5126 \mathrm{~m}$ asl whereas the lowermost area is located in deep valleys of the eastern sector at an elevation of around $3000 \mathrm{~m}$ asl.

Depressions between the individual ranges are mostly occupied by glaciers (Figs. 1 and 2). In the late $1950 \mathrm{~s}$ an estimated $44 \%$ of the entire Ak-Shyirak area has been covered by glaciers (Bondarev, 1963). The highest concentration of glacier-covered area was observed in the central part of the massif whereas glacier cover was smallest in the southern and eastern periphery of the study area. In the central part of the massif accumulation areas of different glaciers partially coalesce into one whereas in the Aktash and Tez catchments small glaciers predominate and have a sporadic distribution (fig. 2). Most ice area is concentrated in the valley glaciers which covered ca. $75 \%$ of the glacierized area of the Ak-Shyirak massif in the late 1950s (Bondarev, 1962). 
The largest glaciers in the massif are Petrov, Dzhaman-Su, Koyandy, and Northern Karasay glaciers. These four glaciers cover ca. $40 \%$ of the total glacier area in the massif. The Ak-Shyirak region has the second largest glacierized area within Tien Shan.

According to data from the Kumtor-Tien Shan weather station (altitude $3659 \mathrm{~m}$ asl) the study area has a cold $\left(\mathrm{MAAT}=-7.5^{\circ} \mathrm{C}\right.$ ) continental climate with coldest temperatures in January (monthly average in $\left.1930-2014:-21.4^{\circ} \mathrm{C}\right)$ and warmest in July $\left(+4.5^{\circ} \mathrm{C}\right)$ (Fig. 1). Precipitation occurs mainly in summer with monthly precipitation of about $50 \mathrm{~mm}$ during May-August whereas November-February is the driest period with measured monthly precipitation of less than $10 \mathrm{~mm}$ (Fig. 1). This low precipitation during winter is explained by the effect of the Siberian High blocking the influx of moist air. The annual sum of precipitation is $317 \mathrm{~mm}$. These dry-cold climatic conditions lead to the widespread occurrence of permafrost in the study area. According to limited geophysical data, glaciers are mostly polythermal or even cold in the snout areas (Petrakov et al., 2014).

As glaciers in the study area receive most precipitation (including snow) during summers, the total accumulation/ablation is much higher than the winter and summer balances (Dyurgerov and Mikhalenko, 1995). As a result, glaciers in the Tien Shan as well as in the Ak-Shyirak massif are highly sensitive to changes in summer temperature (e.g., Kriegel et al., 2013). Increase of summer temperature leads not just to increased ablation through ice melt but also to a reduced share of solid precipitation (i.e. accumulation), even if the total amount of annual precipitation remains constant. Increase of summer temperatures accompanied by decrease of summer (and annual) precipitation has been reported for the Inner Tien Shan by Aizen et al. (2007) and Kutuzov and Shahgedanova (2009).

\section{Material and Methods}

\subsection{Satellite images}


To assess the glacier covered area in the Ak-Shyirak massif in 2003 and 2013, a Terra ASTER image acquired on 19 August 2003, with a spatial resolution of $15 \mathrm{~m} /$ pixel and a SPOT-5 panchromatic image acquired on 25 September 2013, with a spatial resolution of $2.5 \mathrm{~m} / \mathrm{pixel}$ were used for analysis (Fig. 3). Terra ASTER images acquired on 20 September 2003 and 14 August 2004 as well as a SPOT-2 panchromatic image with a spatial resolution of 10m/pixel acquired on 27 August 2006 were used as supplementary data to obtain additional information in some areas with difficult mapping conditions such as snow or debris cover. For the same reason we also referred to Google Earth $^{\circledR}$ to analyze high resolution Digital Globe images for some part of the Ak-Shyirak massif. All images and maps were re-projected into 1984 WGS UTM zone N44 projection and then co-registered using the SPOT-5 data as a master image. All images were clear of clouds and were taken near the end of the ablation season when glacier boundaries are the most visible because of the limited extent of snow cover.

Mosaics from four sheets of former Soviet Union topographic maps from the 1980s (at a scale of 1:50,000) and a digital elevation model (DEM) from the Shuttle Radar Topography Mission (SRTM3) were used for orthorectification of the Terra ASTER, SPOT-2 and SPOT-5 data using the ScanEx Image Processor software, version 4.2. The orthorectification Root Mean Square Error (RMSE) for the 18 ground control points was 2.7 and $10 \mathrm{~m}$ for the SPOT-5 and Terra ASTER images, respectively.

To validate modelled volume change we also acquired high-resolution satellite optical stereo data from Quickbird (1 September 2003, 0.6 m resolution) and GeoEye-1 (29 July 2012, $0.5 \mathrm{~m}$ resolution) over eight glaciers in the SW part of the Kuiloo Range (see Fig.7c). Details about these data can be found in Kronenberg et al. (2016), who, however, produced and analyzed repeat DEMs over only one glacier in our much larger study area.

\subsection{Extraction of glacier outlines}


The semi-automatic approach, which is based on the thresholding of ratio images, has been commonly used for the delineation of glacier outlines since the early 2000s (Paul and Kääb, 2005; Narama et al., 2009; Bhambri et al., 2013). Despite the fact that this approach is time efficient for large-scale inventories, it still requires manual corrections in many cases (Bolch et al., 2010). Furthermore the approach cannot be used for panchromatic SPOT-5 images. We also note that human interpretation remains the best tool for extracting detailed information from satellite imagery for glaciers (Raup et al., 2007), especially when mapping is done by the same person using a combination of different types of imagery (Paul et al., 2002).

To achieve maximum accuracy and due to the relatively small number of glaciers in our study area, we chose manual delineation of glacier boundaries by one single person to map glacier outlines. In areas where glaciers were free from debris cover, boundaries were defined from the change of brightness from one pixel to another. In areas covered by debris we used features indicating ice movement, convex morphological shapes and sources of streams as limits of glacier termini. As debris cover occurs only on a relatively small part of the Ak-Shyirak glacier area, representing just $1 \mathrm{~km}^{2}$ of the six largest glaciers according to Aizen et al. (2007), potential impacts of inaccuracies related to debris cover can be considered limited. In addition, glaciers with joint accumulation areas were separated along topographic ice divides, which were visually traced using a hillshaded relief of the ASTER GDEM v.2 (www.gdem.ersdac.jspacesystems.or.jp).

After delineation of the glacier boundaries, the area of each individual glacier polygon was computed in ArcGIS 10.1. Other glaciological parameters, such as minimum, maximum and mean elevation, and aspect, were obtained by intersecting the glacier outlines with the ASTER GDEM v.2.

\subsection{Uncertainty assessment for glacier area}


Uncertainties in glacier surface area relate to (i) errors in georeferencing of satellite images and (ii) errors in delineation of glacier boundaries. The first set of errors depends on the quality of co-registration of satellite images and DEMs used for orthorectification. In the present case, Visual inspection of overlapped images revealed good matches with an RMSE of $2.7 \mathrm{~m}$. The second source of errors, i.e. delineation errors, depends on image resolution and observation conditions at the time of acquisition, namely cloud and snow cover, presence of shadows and debris covered ice. In our case clouds were absent, snow cover was close to a minimum and deep shadows were practically absent.

Image resolution has an impact on the quality of glacier delineation (Hagg et al., 2012) and thus on the determination of glacier covered area. Following O'Gorman (1996) and Pieczonka and Bolch (2015) for glaciological applications we assume that the maximum error of the area determination is in the order of half a pixel. For each glacier this error has been assessed by buffering the glacier perimeter considering the area uncertainty. Buffer width was $7.5 \mathrm{~m}$ for Terra ASTER and $1.25 \mathrm{~m}$ for SPOT-5. The total uncertainty in the glacier coverage assessment for the whole Ak-Shyirak area was then determined as the sum of all the buffer areas. It was \pm 9.7 $\mathrm{km}^{2}$ or $2.6 \%$ for 2003 (Terra ASTER) and $\pm 1.9 \mathrm{~km}^{2}$ or $0.5 \%$ for 2013 (SPOT-5). About $3 \%$ of the total glacier area in Ak-Shyirak is debris covered. For some small glaciers with substantial debris cover the additional error may reach up to $13 \%$. These cases are very limited and the total uncertainty for the glacier area was assessed as $\pm 11.2 \mathrm{~km}^{2}$ or $3.0 \%$ for 2003 (Terra ASTER) and $\pm 5.6 \mathrm{~km}^{2}$ or $1.6 \%$ for 2013 (SPOT-5) and the total uncertainty for the area change was estimated as $\pm 12.3 \mathrm{~km}^{2}$ or $3.4 \%$ (root sum of squares, RSS, of the uncertainty of the two area estimates).

\subsection{Assessment of glacier volume}


For the assessment of glacier volumes in the Ak-Shyirak massif we applied two different volume estimation approaches, namely the VA scaling and the modelling of ice thickness distribution using the GlabTop model (Paul and Linsbauer, 2012). The choice of approaches is driven by the lack of data required for more complex modelling (e.g., Farinotti et al., 2009; Huss and Farinotti, 2012).

\subsubsection{Volume-area scaling}

Developed in the 1960s as an empirical relationship (Erasov, 1968) and further theoretically justified (Bahr, 1997; Bahr et al., 1997), the VA scaling has been the most frequently used approach for regional (e.g. Bolch et al., 2012; Chen and Ohmura, 1990; Cogley, 2011; Frey et al., 2013; Macheret, 1988) and global (Radic and Hock, 2010; Grinsted, 2013) glacier volume estimates. Despite the fact that the VA scaling has disadvantages (Farinotti and Huss, 2013; Frey et al., 2014), this approach provides the simplest method to roughly estimate the order of magnitude of glacier volume changes from repeat glacier areas. For some fundamental concerns and discussion of the approach see Haeberli (2016). Here, our aim is to illustrate the difference of this approach with a more physically-based one. Principally, the ice volume is calculated as a function of area according to equation (1) showing the general form of VA scaling:

$$
\mathrm{V}=\mathrm{kA}^{\gamma}
$$

where $\mathrm{V}$ is glacier volume, $\mathrm{A}$ is glacier area and $\mathrm{k}$ and $\gamma$ are two scaling parameters. Bahr (1997) defined $\gamma=1,375$ for mountain glaciers. In our study we have used different values of $\mathrm{k}$ and $\gamma$ as shown in Table 1.

Table 1. Parameters of the applied VA relations. Volumes are calculated in $m^{3}$ for input glacier areas measured in $\mathrm{m}^{2}(1)$ and in $\mathrm{km}^{3}$ for input glacier areas measured in $\mathrm{km}^{2}$ (2-4).

\begin{tabular}{|l|l|l|l|}
\hline No & Reference & $\mathrm{k}$ & $\gamma$ \\
\hline
\end{tabular}




\begin{tabular}{|l|l|l|l|}
\hline 1 & Bahr et al., 1997 & 0.191 & 1.375 \\
\hline 2 & Macheret et al., 1988 & 0.0298 & 1.379 \\
\hline 3 & Grinsted, 2013, glaciers less than $25 \mathrm{~km}^{2}$ & 0.0435 & 1.23 \\
\hline 4 & Grinsted, 2013, glaciers more than $25 \mathrm{~km}^{2}$ & 0.0540 & 1.20 \\
\hline
\end{tabular}

\subsubsection{Modelling of ice thickness distribution with GlabTop}

Haeberli and Hoelzle (1995) developed a physically-based approach for the assessment of glacier volumes based on the mean surface slope along centerline. Following the same approach, Paul and Linsbauer (2012) developed the GlabTop model which allows assessment of the spatial distribution of ice thicknesses. GlabTop uses glacier outlines, DEM and central flowlines of each glacier branch as main input data (Linsbauer et al., 2012). The model allows estimation of ice thicknesses at several base points along glacier centerlines and interpolation of data between these points and the glacier boundaries. The model has been applied to the Alps (Linsbauer et al., 2012), but also to the HinduKush-Karakoram-Himalayas (HKH; Frey et al., 2014). A detailed description of this model is given in (Paul and Linsbauer, 2012).

It is assumed in the model that the shear stress at the glacier bed is constant along the central line of the glacier (Nye, 1952), and that glacier flow is laminar. Then ice thickness along the glacier's centerline may be calculated with equation (2):

$$
h=\frac{\tau}{f \rho g \sin \alpha}
$$

where $h$ is ice thickness (in $\mathrm{m}) ; \tau$ is basal shear stress $(\mathrm{kPa}) ; f$ is the shape factor; $\rho$ is density of ice $\left(900 \mathrm{~kg} / \mathrm{m}^{3}\right) ; g$ is gravitational acceleration constant $\left(9.81 \mathrm{~m} / \mathrm{s}^{2}\right) ; \alpha$ is surface slope along the centerline of the glacier (in degrees).

Basal shear stress $\tau$ can be calculated for each glacier from the empirical relation based on the difference of altitude $(\Delta H)$ between the highest and the lowest point of the glacier under investigation (Haeberli and Hoelzle, 1995): 


$$
\tau=0.005+1.598 \Delta H-0.435 \Delta H^{2}
$$

The shear stress $\tau$ can be found by reverse calculation, by substituting the known values of ice thickness in equation (2). For ice thickness estimation we used the GlabTop model reconstructed on the basis of publications (Paul and Linsbauer, 2012; Linsbauer et al., 2012). The difference of altitude for glaciers in the Ak-Shyirak massif as well as the surface slope were extracted from the (i) ASTER GDEM V2 and (ii) SRTM DEM; the model was then run for both DEMs. The shape factor $f$ is related to resistance arising on the glacier borders as a result of friction between moving ice and valley slopes and may vary from 0.5 to 0.9 (Paterson, 1994). For valley glaciers with elliptic cross section the recommended value of $f$ is 0.8 (Nye, 1965). The centerlines were manually digitized along the main branches of glaciers, perpendicular to contours. Each centerline was converted into a $100 \mathrm{~m}$ raster band and separated in $50 \mathrm{~m}$ elevation bins. The use of the elevation bands has its advantage as the averaging distance changes automatically depending on the surface slope e.g. larger for flat areas. Similar to (Paul and Linsbauer, 2012) smoothed slope was then averaged within the $50 \mathrm{~m}$ sectors. Ice thickness was calculated for centroids of each sector using equation (2). The ice thickness was interpolated between the points along the flow centerlines and the glacier boundaries with ice thickness equal to zero using Topo to Raster tool in ArcGIS. Glacier volumes were also calculated in ArcGIS.

\subsubsection{Validation of volume-area scaling and GlabTop modelling}

Both approaches were validated using existing regional data.

Taking into account that applying of VA scaling for individual glaciers is not recommended (Bahr et al., 2015) we cannot validate results using geophysical data. For rough validation of VAscaling we used data on volumetric losses of Ak-Shyirak glaciers in 1943-2000 obtained by Aizen et al. (2007) by comparison of multi-temporal DEMs. We compare our 
assessments of glacier volume to information published in the Soviet Glacier Inventory (Katalog, 1969; Katalog, 1970; Katalog, 1979) which reflects the situation of the late 1950s to early 1960s with volume calculated from 2003 glacier areas.

To evaluate GlabTop model uncertainties, the following approaches have been used.

1. We used areal geophysical data from Sary-Tor Glacier where $17 \mathrm{~km}$ of ice thickness measurement tracks were completed in May 2013 using a monopulse VIRL-6 GPR with a central frequency of $20 \mathrm{MHz}$ (Petrakov et al., 2014). In addition we used data from Glacier No.354 published in Hagg et al. (2012) and our data from Davydov Glacier (Lavrentiev et al., 2014). The ice thicknesses determined by GPR measurements at Davydov Glacier (Lavrientiev et al., 2014), SaryTor Glacier (Petrakov et al., 2014), Glacier No. 354 (Hagg et al., 2012) at 141 points were directly compared with GlabTop modelling.

2. Two DEMs with spatial resolutions of 1.2 and $1 \mathrm{~m}$ were generated from the two optical stereo-pairs of Quickbird (1 September 2003) and Geo-Eye (29 July 2012) highresolution satellite imagery using the ScanEx Image Processor software. A detailed description of DEM generation from the same stereo-pairs and related problems is given in Kronenberg et al. (2016). We used the 2003 and 2012 DEMs and images for additional GlabTop modelling of ice thickness. Eight glaciers were delineated on both images. Changes of glacier ice thickness and volumes between 2003 and 2012 obtained through GlabTop were compared to the difference of glacier volumes obtained from differencing the two DEMs.

\section{Results and discussion}

\subsection{Glacier inventory 2013}

A total of 193 glaciers with an area of $351 \mathrm{~km}^{2}$ have been delineated in the SPOT-5 image (Fig. 4). Among them, 26 small glaciers with a total area of $3.4 \mathrm{~km}^{2}$ were not listed in the Soviet 
Glacier Inventory (Katalog, 1969; Katalog, 1970; Katalog, 1979). For each glacier, we determined area, length, minimum, maximum and mean elevations, mean slope and aspect, and grouped them according to their location within hydrological units (see Table 2). We also determined the morphological type as well as hypsography in $100 \mathrm{~m}$ elevation bins for all glaciers. Most of the glaciers (137 or $72 \%$ ) mapped in the study region are smaller than $1 \mathrm{~km}^{2}$ and 25 of these glaciers are smaller than $0.1 \mathrm{~km}^{2}$. Glaciers less than $1 \mathrm{~km}^{2}$ cover ca. $12 \%$ of the total glacierized area, whereas glaciers larger than $1 \mathrm{~km}^{2}(29 \%)$ cover $88 \%$ of the total area. Five glaciers larger than $10 \mathrm{~km}^{2}$ contain $43 \%$ of the total area and seven glaciers with areas between 5 and $10 \mathrm{~km}^{2}$ contribute $14 \%$ to the total area. Glaciers with areas ranging from 1 to $5 \mathrm{~km}^{2}$ cover $31 \%$ of the total glacier area. The large number of small glaciers covering a relatively small area is also typical for the Big Naryn catchment where glaciers less than $1 \mathrm{~km}^{2}(83 \%)$ have been found to contribute $26 \%$ to the total area (Hagg et al., 2012).

A majority of the glacier-covered area is concentrated in the Kumtor and Karasay catchments (Table 2), where the mean area of individual glaciers is also larger than elsewhere in the study region.

Glaciers are located at elevations between 3700 and $5100 \mathrm{~m}$ asl, with ca. $50 \%$ of the total glacier area being concentrated at elevations of 4200-4500 m asl (Fig. 4c), i.e. close to the equilibrium line altitude. The distribution of glacier aspect shows significant differences between individual catchments and depends on prevailing aspect of the catchment. In catchments located in the outer parts of the massif, like Kumtor and Sary-Chat, N, NE and NW oriented glaciers are dominating, whereas $S$ oriented glaciers are most frequently observed at Aktash and Tez. In the Karasay, Dzhaman-Su, Chomoy and Koyandy catchments, located in the inner part of the massif, the aspect of glaciers is more complex. Distribution of glacier aspect derived from individual cells (Paul, 2010) is presented in Fig. 4a. More than 50\% of the glacierized area are N, NE and NW oriented cells. ASTER GDEM v.2-derived mean slope of glacier area in the Ak-Shyirak massif is $19^{\circ}$, but the median slope is $15^{\circ}$. 
Our assessment of glacier-covered area in the Ak-Shyirak massif in $2003\left(373.2 \pm 11.2 \mathrm{~km}^{2}\right)$ is very close to the value of $371.6 \mathrm{~km}^{2}$ obtained by Aizen et al. (2007) using manual delineation of the same ASTER image as used in this study. The same is true for the number of glaciers: whereas Aizen et al. (2007) identified 177 glaciers in their survey, we identified 178 glaciers. Using manual delineation of SPOT-5 scenes, Hagg et al. (2012) reported that glacier area in the Kumtor and Karasay catchments was $181.3 \mathrm{~km}^{2}$ in 2007 , whereas our data show an area of 183.9 $\mathrm{km}^{2}$ in 2003 and $175.1 \mathrm{~km}^{2}$ in 2013.

The glacier-covered area in the Ak-Shyirak massif in 2013 was $351.2 \pm 5.6 \mathrm{~km}^{2}$. This value is slightly higher than the values reported by Pieczonka and Bolch (2015) using automatic delineation of glaciers from Landsat TM scenes with partial manual correction using SPOT-5 scenes (area $348 \pm 10 \mathrm{~km}^{2}$ for 2008 ). We also note that the same authors obtained a glacier area of $382 \mathrm{~km}^{2}$ for 1975 which is also smaller than the values $\left(406 \mathrm{~km}^{2}\right)$ obtained by Aizen et al. (2007) who worked on 1977 data. In summary, we can conclude that all differences mentioned above are within their range of uncertainty.

\subsection{Change in area and number of glaciers}

Changes in glacier-covered areas in the Ak-Shyirak massif in 1943-1977 and 1977-2003 were analyzed in detail by Aizen et al. (2006, 2007). Therefore our analysis will mostly concentrate on the most recent changes between 2003 and 2013 (see Table 2).

Table 2. Number and area of glaciers for major catchments in the Ak-Shyirak massif.

\begin{tabular}{|l|r|r|r|r|}
\hline \multirow{2}{*}{ Catchment } & \multicolumn{2}{|c|}{} & \multicolumn{2}{c|}{ Glacier covered area, $\mathbf{k m}^{2}$} \\
\hline & 2003 & 2013 & 2003 & 2013 \\
\hline Koyandy & 18 & 18 & $59.1 \pm 1.7$ & $55.4 \pm 1.0$ \\
\hline
\end{tabular}




\begin{tabular}{|c|c|c|c|c|}
\hline Aktash & 8 & 8 & $6.3 \pm 0.3$ & $5.5 \pm 0.1$ \\
\hline Tez & 9 & 9 & $4.2 \pm 0.2$ & $3.8 \pm 0.1$ \\
\hline Karasay & 28 & 31 & $73.2 \pm 1.8$ & $70.6 \pm 0.7$ \\
\hline Kumtor & 15 & 16 & $110.7 \pm 2.6$ & $104.5 \pm 1.5$ \\
\hline Sary-Chat & 28 & 31 & $35.1 \pm 1.1$ & $32.5 \pm 0.4$ \\
\hline Chomoy & 4 & 4 & $16.6 \pm 0.7$ & $15.7 \pm 0.2$ \\
\hline Dzhaman-Su & 13 & 15 & $52.6 \pm 2.0$ & $49.1 \pm 1.3$ \\
\hline Kurga-Tepchi & 21 & 24 & $12.2 \pm 0.6$ & $11.1 \pm 0.4$ \\
\hline Small catchments & 4 & 4 & $3.4 \pm 0.2$ & $3.0 \pm 0.1$ \\
\hline Ak-Shyirak, in total & 179 & 193 & $373.2 \pm 11.2$ & $351.2 \pm 5.6$ \\
\hline
\end{tabular}

During this period the number of glaciers in the Ak-Shyirak massif increased from 179 to 193. These 14 new glaciers formed as a result of detachment of tributaries from the main trunks of large and medium-sized glaciers. For example, Petrov Glacier produced, by separation, two new glaciers with a total area of slightly less than $1.5 \mathrm{~km}^{2}$, and N. Karasay Glacier gave birth to one new glacier with an area of $2.4 \mathrm{~km}^{2}$. Mean glacier area in the Ak-Shyirak massif decreased from $2.10 \mathrm{~km}^{2}$ in 2003 to $1.87 \mathrm{~km}^{2}$ in 2013. By contrast, we did not observe cases of disappearance of glaciers during the period 2003-2013. We also note that Bondarev (1963) has listed 131 glacier in the Ak-Shyirak massif during the compilation of the first Soviet Glacier Inventory and that the mean glacier area at that time was close to $3.3 \mathrm{~km}^{2}$.

Over the last decade, the total glacier-covered area in the Ak-Shyirak massif has decreased from $373.2 \pm 11.2 \mathrm{~km}^{2}$ to $351.2 \pm 5.6 \mathrm{~km}^{2}$. Total shrinkage was equal to $22 \pm 12.3 \mathrm{~km}^{2}$ or $5.9 \pm 3.4 \%$ of the glacier area in 2003. Annual area loss was $0.59 \pm 0.34 \% \mathrm{a}^{-1}$, with loss of glacier area caused mostly by terminus retreat (Fig. 5). Mean rate of terminus retreat for this period was $110 \mathrm{~m}$ or 11 m per year. An estimated $1.5 \mathrm{~km}^{2}$ or almost $7 \%$ of the total glacier area loss is explained by direct technogenic impact on Davydov Glacier where a significant part of the glacier snout was 
removed and/or buried under thick rock heaps (Fig. 9). By contrast, we do not observe significant changes in the glacier headwaters. Relative glacier area loss for major catchments differs from $3.6 \%$ in Karasay to $4.9 \%$ in Chomoy, $5.5 \%$ in Kumtor to $9.5 \%$ in Tez and $12.5 \%$ in Aktash (Fig. 5). Ca. 50\% of glacier area loss happened for W, SW and S oriented cells (Fig. 4b). Maximum relative loss (more than 11\%) was also observed for SW aspect whereas minimum relative loss was found for the NE sector (less than 3\%).

No correlation was found between the individual glacier size and relative area loss. By contrast, significant correlation $(\mathrm{R}=0.73)$ can be found between mean glacier size and relative area loss for major catchments. The most intense relative area shrinkage was observed in the Aktash, Tez and Kurga-Tepchi (Fig. 4) where glaciers are isolated and thus could be more prone to regional warming due to, for instance, the action of long-wave radiation from the surrounding slopes (Olyphant, 1986).

Other studies are generally in agreement with our results, and where multiple periods were considered, they also confirm acceleration of shrinkage in recent times. On the basis of a comparison of topographic maps and glacier outlines derived from ASTER imagery, Aizen et al. (2007), for instance, reported that area shrinkage in the Ak-Shyirak region was 4,2\% from 1943 to 1977 , and $8,6 \%$ between 1977 to 2003 , which corresponds to an annual area shrinkage of $0.12 \% \mathrm{a}^{-1}$ and $0.33 \% \mathrm{a}^{-1}$, respectively. Kriegel et al. (2013) compared data from glacier outlines extracted from 1970s Landsat MSS for Kumtor and Karasay catchments with glacier outlines obtained from Landsat TM images in the 2000s and found an area shrinkage of $13 \%$, thus resulting in slightly higher annual losses but still comparable to the data of Aizen et al. (2007). For the same catchments, Hagg et al. (2013) used the Soviet Glacier Inventory and glacier outlines derived from SPOT-5 imagery and report 14\% glacier area shrinkage between 1943 and 2007 or an annual loss of $0.2 \% \mathrm{a}^{-1}$. Pieczonka and Bolch (2015) compared glacier areas obtained by interpretation of Hexagon KH-9, Landsat and SPOT-5 images for the period 1975-2008 and reported total and annual losses for the AkShyirak massif of $8.8 \pm 4.8 \%$ and $0.27 \pm 0.15 \% \mathrm{a}^{-1}$ 
respectively. By contrast, Khromova et al. (2003) reported $23 \%$ of glacier area shrinkage for the period 1977-2001 and thus annual losses close to $1 \%$ which is significantly higher than data obtained in all the other available assessments.

The annual shrinkage rate of glacier area over the second half of the $20^{\text {th }}$ century in different outer ranges of the Tien Shan varied from 0.40 to $0.63 \%$ (Narama et al., 2010), $0.54 \%$ (Bolch, 2007) and 0.76\% (Niederer et al., 2008) per year. In the Inner Tien-Shan ranges, the annual shrinkage rates varied from $0.12 \%$ in the mid $-20^{\text {th }}$ century (Aizen et al., 2007) to $0.27 \%$ (Pieczonka and Bolch, 2015) or 0.35\% (Kutuzov and Shahgedanova, 2009) by the end of the $20^{\text {th }}$ century. For the early $21^{\text {st }}$ century, Narama et al. (2010) report an increase in annual area loss rate in comparison to the $1970-2000$ s from $0.4 \%$ to $0.57 \%$ in At-Bashy (Inner ranges) and Ili-Kungöy (Northern outer ranges) and from $0.63 \%$ to $0.71 \%$ in Pskem (Western outer ranges).

Glaciers of the Ak-Shyirak massif have been fairly stable in comparison to the outer Tien Shan ranges during the mid-20 $0^{\text {th }}$ century (Dyurgerov and Mikhalenko, 1995). By the end of the $20^{\text {th }}$ century, the high glacier shrinkage as observed in the outer ranges did not yet affect the central ranges in general and the AkShyirak massif (Sorg et al., 2012) and Pobeda Peak area in particular (Osmonov et al., 2013, Pieczonka and Bolch, 2015). By contrast, accelerated glacier shrinkage has started to occur in the Ak-Shyirak area in the early $21^{\text {st }}$ century.

Thus, in comparison to other mountain ranges in High Asia the observed glacier behavior in the Ak-Shyirak massif is comparable to the rates observed elsewhere in the larger region, except for the Karakoram Mts. for which no significant glacier area change has been reported for the recent past (Bolch et al., 2012; Bhambri et al., 2013; Minora et al., 2013).

\subsection{Volume of glaciers in the AkShyirak massif in 2003 and 2013}

\subsubsection{Volume-Area scaling}


The assessments of glacier volumes for the years 2003 and 2013, based on VA scaling, are presented in Table 4. According to the values used we obtain a total volume ranging from 28.8 to $32.5 \mathrm{~km}^{3}$ of ice for 2003 and from 26.4 to $30.0 \mathrm{~km}^{3}$ for 2013 , respectively.

Table 3. Volumetric assessments for main catchments in the AkShyirak massif in 2003 and 2013 based on volume-area $(V-A)$ scaling. For scaling parameters used here see Table 1.

\begin{tabular}{|c|c|c|c|c|c|c|}
\hline \multirow{4}{*}{$\begin{array}{l}\text { Datchment } \\
\text { name }\end{array}$} & \multicolumn{6}{|c|}{$\begin{array}{l}\text { Sources for scaling parameters in volumetric } \\
\text { assessments }\end{array}$} \\
\hline & \multicolumn{2}{|c|}{$\begin{array}{l}\text { Bahr et al. } \\
\text { (1997) }\end{array}$} & \multicolumn{2}{|c|}{$\begin{array}{l}\text { Macheret et al. } \\
\text { (1988) }\end{array}$} & \multicolumn{2}{|c|}{ Grinsted (2013) } \\
\hline & \multicolumn{6}{|c|}{ Volumes, $\mathrm{km}^{3}$} \\
\hline & 2003 & 2013 & 2003 & 2013 & 2003 & 2013 \\
\hline Koyandy & 4.6 & 4.3 & 4.1 & 3.8 & 4.2 & 3.9 \\
\hline Aktash & 0.2 & 0.2 & 0.2 & 0.2 & 0.3 & 0.2 \\
\hline Tez & 0.1 & 0.1 & 0.1 & 0.1 & 0.2 & 0.1 \\
\hline Karasay & 6.7 & 6.3 & 5.9 & 5.4 & 6.1 & 5.7 \\
\hline Kumtor & 13.0 & 12.0 & 11.6 & 10.7 & 10.7 & 10.0 \\
\hline Sary-Chat & 2.0 & 1.9 & 1.8 & 1.6 & 2.0 & 1.9 \\
\hline Chomoy & 0.9 & 0.9 & 0.8 & 0.7 & 0.9 & 0.9 \\
\hline Dzhaman-Su & 4.3 & 4.0 & 3.8 & 3.4 & 3.8 & 3.5 \\
\hline Kurga-Tepchi & 0.6 & 0.5 & 0.5 & 0.4 & 0.6 & 0.5 \\
\hline AkShyirak & 32.5 & 30.0 & 28.8 & 26.4 & 28.8 & 26.7 \\
\hline
\end{tabular}


The major part of glacier volume is concentrated in the Kumtor and Karasay catchments. We also note that glaciers larger than $10 \mathrm{~km}^{2}$ contribute about $60 \%$ of total ice volume in AkShyirak glaciers (from $19.7 \mathrm{~km}^{3}$ based on Bahr et al. (1997) to $16 \mathrm{~km}^{3}$ based on Grinsted (2013)). Contribution of small (less than $1 \mathrm{~km}^{2}$ ) glaciers to the total ice volume is less than 1 $\mathrm{km}^{3}$. According to VAscaling, the ice losses in 2003-2013 varied within $2.1-2.5 \mathrm{~km}^{3}$ which is roughly equivalent to 5.8-6.9 $\mathrm{m}$ of glacier surface lowering or to 4.9-5.9 $\mathrm{m}$ of loss in $\mathrm{m}$ w.e. assuming mean density at glacier surface as $850 \mathrm{~kg} / \mathrm{m}^{3}$ (Huss, 2013). This value corresponds well with the balance for Glacier No. 354 in the Kumtor catchment for the same period. According to direct measurements and numerical modelling the mass balance of Glacier No.354 during 2003-2013 was about $-4.5 \mathrm{~m}$ w.e., and the geodetically derived mass balance during 2003-2012 was -0.48 $\mathrm{m} \mathrm{a}^{-1}$ (Kronenberg et al., 2016) which gives -4.8 m w.e. during 2003-2013 using simple extrapolation.

We also applied VA scaling to assess volumetric change using data on glacier area published in the Soviet Glacier Inventory and data on glacier area derived from the ASTER 2003 image. Ice losses varied then from $6.1 \mathrm{~km}^{3}$ (Grinsted, 2013) to $7.3 \mathrm{~km}^{3}$ (Bahr et al., 1997). This is lower in comparison to Aizen et al. (2007) who reported $3.6 \mathrm{~km}^{3}$ ice losses during 1943-1977 and an additional $6.1 \mathrm{~km}^{3}$ between 1977 and 2003. Pieczonka and Bolch (2015) reported a geodetically-obtained annual glacier mass balance of the entire Ak-Shyirak massif of $0.51 \pm 0.36$ $\mathrm{m}$ w.e. $\mathrm{a}^{-1}$ for the period $1975-1999$ which is close to a loss of $5.3 \mathrm{~km}^{3}$ of ice and matches well results of Aizen et al. (2007). Underestimation of ice losses obtained by the VAscaling approach could be explained by the specific behavior of continental glaciers where, at some stages of glacier recession, decrease of surface elevation is not accompanied by shrinkage of area (Mikhalenko, 1990), e.g. in 1943-1977 Sary-Tor glacier surface decreased by 19.4 m on average while the area reduction was just $0.08 \mathrm{~km}^{2}$ or $2 \%$ (Kuzmichenok, 1988). Delayed reaction was probably caused by low ice dynamics. 


\subsubsection{GlabTop modelling}

At all glaciers with geophysical thickness data, the modelled ice thicknesses using shear stress $\tau$ calculated from Eq. (3) and $\mathrm{f}=0.8$ mostly are lower in comparison to GPR thickness data. The average difference between modelled and measured ice thicknesses over all validation points was $-15.5 \mathrm{~m}$ and the relative difference was $-16 \%$. The root mean square error (RMSE) for all validation points was $38.3 \mathrm{~m}$ for GlabTop. A negative difference between modelled and measured ice thicknesses has been also reported by Frey et al. (2014) for some glaciers in the HKH region. Mean deviation of modelled and measured ice thicknesses along central flowlines was as follows: at Davydov Glacier -11\% (ASTER GDEM v.2), at SaryTor Glacier -11\% (ASTER GDEM v.2) and -14\% (SRTM DEM) and at Glacier No.354 -16\% and $14 \%$ consequently. A map with differences of modelled (with uncertainty 1.5\% (Petrakov et al., 2014)) and measured ice thickness at SaryTor Glacier is presented in Fig.6. It is clearly visible that at the lower part of the snout GlabTop significantly overestimates ice thickness whereas in the accumulation area and area of snowline migration GlabTop underestimates ice thickness. Similar spatial distribution between modelled and measured ice thicknesses was also noted by Frey et al. (2014). Comparison of modelled and measured volumes for SaryTor Glacier led to $24 \%$ deviation which is within the stated model accuracy of $\pm 30 \%$ (Paul and Linsbauer, 2012).

The GlabTop model has only slightly (less than 6\%) overestimated the mean difference of volume in comparison with the geodetic volume difference from subtracting the 2003 and 2012 satellite stereo DEMs but the standard deviation of differences for individual glaciers is $40 \%$ and for individual glaciers the difference was as high as $-55 \%$ or $+42 \%$. These differences could be partially (ca. 15\%, Kronenberg et al., 2016) explained by uncertainties of our DEMs but values still remain higher than the expected GlabTop model accuracy of $\pm 30 \%$.

Results of the GlabTop modelling are presented in Fig. 7. Ice thickness depends on DEM quality and resolution used for modelling. If we apply the ASTER GDEM v.2, the total glacier volume in the Ak-Shyirak massif is about $13.2 \mathrm{~km}^{3}$. If we use the SRTM DEM, total glacier 
volume is about $18.8 \mathrm{~km}^{2}$. In both cases the largest ice thicknesses are modelled at Petrov Glacier with $280 \mathrm{~m}$ for ASTER GDEM v.2 and $420 \mathrm{~m}$ for SRTM DEM. In general terms we can state that for large glaciers the GlabTop model run with the SRTM DEM yields much larger thicknesses and volumes as compared to ASTER GDEM v.2 (see Fig. 7c, d). Possible reasons could be the stair-stepped terrain in the ASTER GDEM v.2 caused by poor stereocorrelation in wide snow-covered areas and artifacts due to residual cloud cover in some stereopairs. As a consequence the above difference between SRTM-based and ASTER-based GlabTop runs could be very specific for the data and site investigated here, and should not be generalized. For the five glaciers larger than $10 \mathrm{~km}^{2}$, the total volume calculated through SRTM DEM is ca. 12.4 $\mathrm{km}^{3}$. It is $4.9 \mathrm{~km}^{3}$ or $65 \%$ larger in comparison to the volume calculated through ASTER GDEM v.2. For all glaciers with an area smaller than $10 \mathrm{~km}^{2}$ the total volume calculated with the SRTM DEM is $12 \%$ larger in comparison to the values obtained with the ASTER GDEM v.2. For some glaciers, including the Sary-Tor, the SRTM DEM gives smaller values of volume in comparison to ASTER GDEM v.2. We note that correlation between series of glacier volumes calculated through ASTER and SRTM DEMs is very high with $\mathrm{R}^{2}=0.99$. We also tested GlabTop using DEM and glacier outlines generated from a GeoEye stereo image pair. The total volume of eight glaciers within these images estimated using the GeoEye DEM was $2 \%$ lower in comparison to the SRTM DEM and 5\% lower in comparison to the ASTER GDEM v.2.

In all cases VA scaling gives larger glacier volumes in comparison to the GlabTop model. The same was noted by Frey et al. (2014) for the HKH region where in some cases resulting ice volumes for the sub-regions deviated by a factor of 1.6 or more. In their study the accuracy of both methods was assessed by applying a sensitivity test with the specific boundary conditions. The VA scaling was modified by varying the initial glacier covered area by $\pm 5 \%$ which resulted in a total volume variation of $\pm 6.9 \%$. In our case this would lead to an even lower relative difference as higher accuracy of the glacier outlines delineation is assumed $( \pm 3.0 \%$ for area and $\pm 3.7 \div 4.2 \%$ for the scaling approach for the volume in 2003 and $\pm 1.6 \%$ for area and $\pm 1.9 \div 2.2 \%$ 
for the volume in 2013). For the GlabTop model the sensitivity test included the modification of model parameters ( $f$ by \pm 0.1 and $\tau$ max by $\pm 30 \mathrm{kPa}$ ) (Frey et al., 2014). The combination of upper and lower boundary parameters led to a total volume variation of the HKH region from $26 \%$ to $+36 \%$. The latter result is also valid for our estimations. The difference between the VAscaling and slope-dependent model was expected as it was shown before that despite the good agreement of the two methods on a global scale (e.g. Pfeffer et al. 2014, Huss Farinotti 2012) the regional estimations using the VA scaling approach are often overestimating the total volume of glaciers, while the slope-dependent models are able to account for some regional topographic effects (Frey et al., 2014) but generally underestimate ice thickness in comparison to in-situ thickness measurements.

\subsection{Possible drivers of glacier downwasting in the Ak-Shyirak area}

\subsubsection{Climate change}

A series of warm season (May-September or MJJAS) temperatures from the Kumtor-Tien Shan weather station is presented in Fig. 8. We used MJJAS temperatures because all melting and ca. $76 \%$ of annual precipitation occurs during these months. A clear positive and statistically significant trend (at the 0.01 confidence level) is observed for the period of 1930-2014, despite the fact that the station was shifted from 3614 to $3659 \mathrm{~m}$ asl in elevation and $2.5 \mathrm{~km}$ closer to Davydov Glacier. Both the old and the new stations are located in flat areas with the same aspect. Between 1943 and 2013, air temperature has been increasing at a rate $0.02{ }^{\circ} \mathrm{C}$ per year. During 1990 to 2013 , air temperature was growing by up to $0.04{ }^{\circ} \mathrm{C}$ per year. A 7 -year moving average illustrates the general, yet slow increase of MJJAS temperature from 1930 to 1990 with periods of almost stable temperatures between 1975 and 1990 or even a slight decrease of temperatures during 1943-1957. During the period 1990-2000, by contrast, the 7-year moving average clearly indicates a dramatic increase of air temperature with a rate of $0.1^{\circ} \mathrm{C}$ per year. A similar tendency for the same period has been reported for annual temperatures in Naryn (Giese 
et al., 2007). Comparison with data from the Naryn weather station shows that a statistically significant correlation exists with air temperatures throughout the period of observations (19302015) ( $\mathrm{r}=0.8)$. This correlation was not affected by the replacement of the weather station in 1997.

By contrast, we do not observe significant trends in annual sums of precipitations for the period 1930-2014, but a rapid decrease of annual precipitation has been observed for 1981-1997. We also note that according to data from the late 1950s, the vertical gradient of annual precipitation at altitudes of 3600-3700 m asl was $60 \mathrm{~mm}$ per $100 \mathrm{~m}$ elevation (Bondarev, 1963). Precipitation data from the two weather stations (Naryn and Kumtor-Tien Shan) correlate well until $1990(\mathrm{r}=0.5, \mathrm{p}<0.05)$, thereafter, correlation becomes insignificant between 1990 and 1997 $(\mathrm{r}=-0.2)$. Moreover, average annual precipitation was twice lower during the period 1990-1997 as compared to 1930-1990, a change which was not observed for other stations in Tien Shan. Correlation increases again after $1997(\mathrm{r}=0.35)$ but remains insignificant. We conclude that the strong decrease of annual precipitation in the 1990s at Tien Shan station could have been caused by a decrease in measurement quality due to the economic and political instabilities in the region. Also, the methods used to collect precipitation data have changed after 1997. Thus data of precipitation after 1997 can be considered as a separate time series.

As a result of regional climate change, mean MJJAS temperature increased from $+1.7^{\circ} \mathrm{C}$ $(1943-1977)$ to $+2.4^{\circ} \mathrm{C}(1978-2003)$ and $+3.0^{\circ} \mathrm{C}(2004-2013)$. These changes have resulted in a significant increase of glacier ablation and probably in a decrease of the share of solid precipitation during the warm season. Taking into account that the mean MJJAS temperature gradient in Tien Shan is $0.5-0.6^{\circ} \mathrm{C} 100 \mathrm{~m}^{-1}$ (Aizen et al., 1996), the rise in air temperatures as described above also resulted in a significant rise of the equilibrium line altitude (or ELA) during 2004-2013 in comparison to 1943-1977 when glaciers in the Ak-Shyirak massif were mainly stable. An ELA rise of $100 \mathrm{~m}$ in the altitudinal bin of 4200-4500 m means losses of 
accumulation areas close to ca. $15 \%$ of the total glacier area of the Ak-Shyirak massif and thus a strongly negative effect on glacier mass balance.

\subsubsection{Technogenic impact on Ak-Shyirak glaciers}

All results on areal and volumetric change reported above include mined glaciers. Here we try to distinguish the role of technogenic impact from the effect of regional climate change in glacier downwasting in the Ak-Shyirak massif.

Technogenic impacts on glaciers include open-pit excavation (direct impact) and pollution of the glacier surface by dust and related change in albedo (indirect impact). Open-pit ice excavation exists at a few sites in the world, mostly in Greenland (Colgan and Arenson, 2013). As noted by Kronenberg (2013), although changes in glacier area and volume introduced by mining are minor compared to those caused by climate change, society can more easily counteract the latter. This is also true for the Kumtor gold mine where technogenic impacts on glaciers were among the triggers for the initiation of the so-called 'Glacier Law' in Kyrgyzstan. As a consequence, the role of open-pit ice excavation on glacier area loss in the AkShyirak massif has been studied before. According to Khromova et al. (2003), a significant local loss of glacier area has been caused by the direct impact of opencast mining. Parts of the Davydov and Lysyi glaciers with a total area of $0.7 \mathrm{~km}^{2}$ were removed mechanically during the $1980 \mathrm{~s}$ and 1990s. This removal represents $0.6 \%$ of the total area loss in the AkShirak massif in the late $20^{\text {th }}$ century. According to our analyses, $1.5 \mathrm{~km}^{2}$ or less than $7 \%$ from the total glacier area loss in 2003-2013 is explained by the direct technogenic impact on Davydov Glacier where a significant part of the glacier snout was partially removed and partially buried under thick rock heaps and thus cannot be detected anymore in satellite images (see Fig. 9).

According to data from the Kumtor Gold Company, $106 \times 10^{9} \mathrm{~kg}$ of ice were removed from Lysyi and Davydov Glaciers in the period 1995-2013, 88. × 109 $\mathrm{kg}$ of which between 2011 and 2013 (Kumtor Gold..., 2013). This is roughly equal to $0.12 \mathrm{~km}^{3}$ of ice in $1995-2013$ but 0.10 
$\mathrm{km}^{3}$ of ice for the period 2011-2013 or ca. 5\% of the total volumetric losses of AkShyirak massif in 2003-2013 (see Table 3). Noteworthy, the open-access data of the Kumtor Gold Company are also confirmed by Soviet data. In the mid-1980s, according to geophysical data, the volume of Davydov Glacier snout was assessed as $0.16 \mathrm{~km}^{3}$ (Vasilenko et al., 1988). Roughly assuming climate induced ice losses at the Davydov Glacier snout at $0.02 \pm 0.04 \mathrm{~km}^{3}$ during $1985-2000$ (see Fig. 4 from Aizen et al., 2007) and extrapolating the same rate to the early 2000s, we estimate that the volume of the Davydov Glacier snout during the active ice excavation phase has reduced by up to $0.12 \mathrm{~km}^{3}$. This means that most of the ice from the snout has been removed and thereafter buried under the slug rock heaps. This has resulted in a formation of a huge technogenic rock glacier at the site where the upper part of the Davydov Glacier snout has been located earlier. Thick debris prevents the removed ice from melting. Recent movements of this rock glacier and another one in the catchment of the Lysyi Glacier have been described in detail by Jamieson et al. (2015). We conclude that the direct technogenic contribution to the total ice losses in the AkShyirak massif in 2003-2013 might in fact be less than 5\%.

Pollution of the glacier surface by thin layer of dust leads to decreasing of albedo and thus to increasing ablation. For the particular case of the AkShyirak massif, the effect of dust could theoretically be compensated by an increasing albedo due to more frequent summer snowfalls. Earlier studies (e.g., Torgoev and Aleshin, 2001) assess daily emitted dust at the mine site as 3-4 t such that increasing ablation in the area should be expected (Kronenberg, 2013). By contrast, Kuzmichenok (2012), on the basis of data on total suspended particles concentrations in the air, considers the action of the mine site on dust content in the atmosphere and glacier surface negligible. For a rough assessment of the indirect impacts of the Kumtor Gold Company on glacier shrinkage through dust deposition on glaciers, we compared the shrinkage of glacier areas (in \%) to distance to the main pit for 15 glaciers. We consider glaciers with areas similar to Sary-Tor and Lysyi glaciers located the most closely to the mine site. The low correlation coefficient of $\mathrm{R}=0.16$ with a $\mathrm{p}$-value of 0.06 does not support a relation between glacier area 
losses and the distance between glaciers and the main pit. Thus the indirect impact of Kumtor Gold Company activities on glaciers in the Ak-Shyirak massif does not apparently result in a more pronounced shrinkage of glacier area close to the main pit. However, as glacier areas, or terminus positions, would react in a delayed and attenuated way, in particular in the cold-dry climate of the study region, the question remains open as to whether glacier albedo or volume/mass changes of the glaciers under investigation will show a relation with proximity to the mine. Detailed and precise studies of albedo changes and glacier mass balances would be required to this end, exceeding the purpose of this regional-scale research.

\section{Conclusions}

The present study confirms continuous glacier mass loss and accelerated glacier area shrinkage during the period 2003-2013 in the Ak-Shyirak massif, Inner Tien Shan. Both regional climate change and direct technogenic impact through ice excavation and removal contributed to glacier area and mass loss. The role of the latter is one order of magnitude smaller than the total area and mass losses, accounting for less than 7\% and less than 5\%, respectively. The increase of warm season (May-September) temperatures seems responsible for the pronounced glacier retreat.

An updated glacier inventory based on an SPOT-5 image with $2.5 \mathrm{~m} /$ pixel resolution has been compiled for the Ak-Shyirak massif. Glacier-covered area decreased from $373.2 \pm 11.2 \mathrm{~km}^{2}$ in 2003 to $351.2 \pm 5.6 \mathrm{~km}^{2}$ in 2013 which means an annual area decrease of $0.59 \pm 0.34 \%$. This is twice as high as during 1977-2003. During 2003-2013, the shrinkage rate of Ak-Shyirak glaciers was similar to shrinkage rates in Northern and Western Tien Shan glaciers, but much higher in comparison to Central Tien Shan glaciers.

Glacier volume has been assessed using VA scaling and GlabTop modelling approaches. Resulting values for the whole massif differ strongly, from 30.0 to $13.2 \mathrm{~km}^{3}$. Comparison of 
volumetric losses obtained from volume-area scaling with geodetically-derived volume change during 1943-2003 reveals underestimation of ice loss. The GlabTop model results were validated using radio-echo sounding data from three glaciers and revealed systematic underestimating of glacier thickness with a mean deviation value of $16 \%$. In some cases, especially in the accumulation area, underestimation of glacier thickness was up to 50\%. Comparison of GlabTop-modelled volume changes, however, for eight glaciers with geodetically-derived volume change during 2003-2012 reveals a good match (6\% overestimation by GlabTop on average). Despite of differences for individual glaciers being much higher, GlabTop showed thus a good correlation with geodetic glacier volume changes for a small group of glaciers. In particular, for small glaciers, the application of GlabTop using ASTER DEM v.2 and SRTM gives similar results, whereas in the case of large glaciers (more than $10 \mathrm{~km}^{2}$ ) SRTM yields much higher volumes. GlabTop modelling at glacier sections with smoother terrain agrees better with GPR measurements, in comparison to steep accumulation areas where GlabTop tends to significantly underestimate ice thickness, and in comparison to the lowermost parts of the glacier snouts where GlabTop tends to overestimate ice thickness. Thus, more GPR data are needed for more robust glacier volume assessments in Tien Shan.

\section{Acknowledgments}

This work has been supported by a Swiss National Science Foundation Scopes grant (grant no 152301) and a Russian Foundation for Basic Research grant (grant no 15-05-08694). We thank Eric Kozhomkulov (KGC) for providing us with meteorological records from the Kumtor-Tien Shan weather station. A. Kääb acknowledges support by the European Research Council (FP/2007-2013, ERC grant agreement No. 320816) and the European Space Agency project Glaciers_cci (4000109873/14/I-NB). We also would like to acknowledge the constructive and helpful comments and suggestions of two anonymous reviewers and Editor-in-Chief Damia Barcelo which greatly improved the quality of the paper. 


\section{References}

1. Aizen, V.B., Kuzmichenok, V. A., Surazakov, A.B., Aizen, E.M., 2006. Glacier changes in the central and northern Tien Shan during the last 140 years based on surface and remote-sensing data. Ann. Glaciol., 43, 202-213.

2. Aizen, V.B., Kuzmichenok, V.A., Surazakov, A.B., Aizen, E.M., 2007. Glacier changes in the Tien Shan as determined from topographic and remotely sensed data. Glob. Planet. Chang., 56, 328-340.

3. Aizen V.B., Aizen E.M., Surazakov A.B., Nikitin S.A., 2008. Is Central Asia really exsiccated? // Proc. of the AGU Fall Meeting, San Francisco, GC53C-07.

4. Arendt, A., T. Bolch, J.G. Cogley, A. Gardner, J.-O. Hagen, R. Hock, G. Kaser, W.T. Pfeffer, G. Moholdt, F. Paul, V. Radić, L. Andreassen, S. Bajracharya, N. Barrand, M. Beedle, E. Berthier, R. Bhambri, A. Bliss, I. Brown, D. Burgess, E. Burgess, F. Cawkwell, T. Chinn, L. Copland, B. Davies, H. De Angelis, E. Dolgova, K. Filbert, R.R. Forester, A. Fountain, H. Frey, B. Giffen, N. Glasser, S. Gurney, W. Hagg, D. Hall, U.K. Haritashya, G. Hartmann, C. Helm, S. Herreid, I. Howat, G. Kapustin, T. Khromova, C. Kienholz, M. Köonig, J. Kohler, D. Kriegel, S. Kutuzov, I. Lavrentiev, R. Le Bris, J. Lund, W. Manley, C. Mayer, E. Miles, X. Li, B. Menounos, A. Mercer, N. Mölg, P. Mool, G. Nosenko, A. Negrete, C. Nuth, R. Pettersson, A. Racoviteanu, R. Ranzi, P. Rastner, F. Rau, B. Raup, J. Rich, H. Rott, C. Schneider, Y. Seliverstov, M. Sharp, O. Sigurðsson, C. Stokes, R. Wheate, S. Winsvold, G. Wolken, F. Wyatt, N. Zheltyhina, 2012. Randolph Glacier Inventory - A Dataset of Global Glacier Outlines: Version 3.2. Global Land Ice Measurements from Space, Boulder Colorado, USA. Digital Media. 
5. Bahr, D.B., 1997. Global distributions of glacier properties: a stochastic scaling paradigm. Water Res. Res. 33, 1669-1679.

6. Bahr, D. B., Meier, M. F., and Peckham, S. D., 1997. The physical basis of glacier volume-area scaling, J. Geophys. Res., 102, 20355- 20362, doi:10.1029/97JB01696.

7. Bahr, D. B., W. T. Pfeffer, and G. Kaser, 2015. A review of volume-area scaling of glaciers. Rev. Geophys., 53, 95-140. doi: 10.1002/2014RG000470.

8. Beniston, M., Stoffel, M., and Quevauviller, P., 2014 The impacts of climatic change on water resources: Foreword to the Special Issue. J. Hydrol., 518, 179 (doi: 10.1016/j.jhydrol.2014.06.029)

9. Bhambri R., Bolch T., Kawishwar P., Dobhal D. P., Srivastava D., and Pratap B., 2013. Heterogeneity in glacier response in the upper Shyok valley, northeast Karakoram. Cryosphere 7, 1385-1398.

10. Bolch T., 2007. Climate change and glacier retreat in northern Tien Shan Kazakhstan/Kyrgyzstan) using remote sensing data. Glob. Planet. Chang. 56, p.1-12.

11. Bolch, T., Menounos, B., Wheate, R, 2010. Landsat-based inventory of glaciers in western Canada, 1985-2005. Remote Sens. Environ. 114, p.127-137

12. Bondarev L.G., 1963. Essays on glaciation of the AkShyirak massif. AN Kyrg. SSR, Frunze, 203 p.

13. Chen, J., and A. Ohmura, 1990. Estimation of Alpine glacier water resources and their change since the 1870s. IAHS Publ. 193, 127-135.

14. Citterio, M., Diolaiuti, G., Smiraglia, C., D’agata, C., Carnielli, T., Stella, G., and Siletto, G. B., 2007. The fluctuations of Italian glaciers during the last century: a contribution to knowledge about 5 Alpine glacier changes, Geogr. Ann. A, 89, 164-182

15. Citterio M, Mottram R, Larsen SH, Ahlstrøm A., 2009. Glaciological investigations at the Malmbjerg mining prospect, central East Greenland. Geological Survey of Denmark and Greenland Bulletin 17, 73-76. 
16. Clague J.J., 2013. Cryospheric hazards. Geology today 29(2), 73-79

17. Cogley, J. G., 2011. Present and future states of Himalaya and Karakoram glaciers, Ann. Glaciol., 52, 69-73.

18. Colgan W., Arenson L.U., 2013. Open-pit Glacier Ice Excavation: Brief Review. J.Cold Regions Engineering 27(4), 223-243.

19. Diolaiuti, G., Bocchiola D., D’Agata C., Smiraglia C., 2012. Evidence of climate change impact upon glaciers' recession within the Italian Alps - The case of Lombardy glaciers. Theor. Appl. Climat. 109, 429-445.

20. Dyurgerov M.B., 2010. Reanalysis of Glacier Changes: From the IGY to the IPY, 19602008. Data Glaciol. Stud. 108, 6-115.

21. Dyurgerov M B and Mikhalenko V N eds., 1995. Oledeneniye Tien Shanya (Glaciation of Tien Shan), VINITI, Moscow (In Russian).

22. Engel Z., Sobr M., Yerokhin SA., 2012. Changes of Petrov glacier and its proglacial lake in the Akshiirak massif, central Tien Shan, since 1977. J. Glaciol. 58 (208) 388-398.

23. Erasov, N.V., 1968. Method to determine the volume of mountain glaciers. Data Glaciol. Stud. 14, 307-308 (in Russian).

24. Farinotti, D., Huss, M., Bauder, A., Funk, M., Truffer, M., 2009. A method for estimating the ice volume and ice thickness distribution of alpine glaciers. J. Glaciol. 191, 422-430.

25. Frey, H., Machguth, H., Huss, M. et al., 2014. Ice volume estimates for the HimalayaKarakoram region: evaluating different methods. Cryosphere 8, 2313-2333.

26. Fujita, K., Takeuchi, N., Nikitin, S.A., Surazakov, A.B., Okamoto, S., Aizen, V.B., Kubota, J., 2011. Favorable climatic regime for maintaining the present-day geometry of the Gregoriev Glacier, Inner Tien Shan. Cryosphere 5, 539-549.

27. Giese, E., Moßig, I., Rybski, D., Bunde, A., 2007. Long-term analysis of air temperature trends in Central Asia. Erdkunde 61, 186-202.

28. Grinsted, A., 2013. An estimate of global glacier volume. Cryosphere 7, 141-151. 
29. Haeberli, W., 2016. Brief communication: On area- and slope-related thickness estimates and volume calculations for unmeasured glaciers. Cryosphere Discuss., doi:10.5194/tc2015-222.

30. Haeberli, W., Hoelzle, M., 1995. Application of inventory data for estimating characteristics of and regional climate-change effects on mountain glaciers: A pilot study with the European Alps. Ann. Glaciol., 21, 206-212.

31. Hagg W., Mayer C., Lambrecht A., Kriegel D., Azizov E., 2013. Glacier changes in the Big Naryn basin, Central Tian Shan. Glob. Planet. Chang. 110A, 40-50, DOI:10.1016/j.gloplacha.2012.07.010.

32. Huss M., 2013. Density assumptions for converting geodetic glacier volume change to mass change. Cryosphere 7(3), 877-887

33. Huss, M. and Farinotti, D., 2012. Distributed ice thickness and volume of all glaciers around the globe, J. Geophys. Res, 117, F04 010, doi:10.1029/2012JF002523

34. IPCC. Climate Change 2007: The Physical Science Basis. Contribution of Working Group 1 to the Fourth Assessment Report of the Intergovernmental Panel on Climate Change (eds. S. Solomon, D. Qin, M. Manning, Z. Chen, M.C. Marquis, K. Averyt, M. Tignor and H.L. Miller). Intergovernmental Panel on Climate Change, Cambridge and New York, 2007, 996 pp.

35. Jamieson, S. S. R., M. W. Ewertowski, and D. J. A. Evans, 2015. Rapid advance of two mountain glaciers in response to mine-related debris loading. J. Geophys. Res. Earth Surf., 120, 1418-1435. doi: 10.1002/2015JF003504.

36. Janský, B., Engel, Z., Šobr, M., Yerokhin, S., Beneš, V., Špaček, K., 2009. The Evolution of Petrov Lake and Moraine Dam Rupture Risk (Tien-Shan, Kyrgyzstan). Nat. Hazards 50 (1), 83 -96. doi: 10.1007/s11069-008-9321-8.

37. Kääb, A., Berthier E., Nuth C., Gardelle J., Arnaud Y., 2012. Contrasting patterns of early twenty-first-century glacier mass change in the Himalayas. Nature 488, 495-498. 
38. Kääb, A., Treichler, D., Nuth, C., Berthier, E., 2015. Brief Communication: Contending estimates of 2003-2008 glacier mass balance over the Pamir-Karakoram-Himalaya. Cryosphere 9, 557-564, doi:10.5194/tc-9-557-2015, 2015.

39. Katalog Lednikov SSSR (Catalogue of Glaciers of the USSR), 1977. Vol. 14. Central Asia, 1-5, Leningrad, Gidrometeoizdat, 79 p. (in Russian).

40. Katalog Lednikov SSSR (Catalogue of Glaciers of the USSR), 1970. Vol. 14. Central Asia, 2-6, Leningrad, Gidrometeoizdat, 54 p. (in Russian).

41. Katalog Lednikov SSSR (Catalogue of Glaciers of the USSR), 1969. Vol. 14. Central Asia, 2-7, Leningrad, Gidrometeoizdat, 57 p. (in Russian).

42. Khromova, T.E., Dyurgerov, M.B., Barry, R.G., 2003. Late-twentieth century changes in glacier extent in the Ak-shirak Range, Central Asia, determined from historical data and ASTER imagery. Geophys. Res. Let. 30(16), 1863, doi:10.1029/2003GL017233

43. Kriegel, D., Mayer, C., Hagg, W., Vorogushyn, S., Duethmann, D., Gafurov, A., Farinotti, D., 2013. Changes in glacierisation, climate and runoff in the second half of the 20th century in the Naryn basin, Central Asia. Glob. Planet. Chang. 110, 51-61. http://dx.doi.org/10.1016/j.gloplacha.2013.05.014.

44. Kronenberg, M., Barandun, M., Hoelzle,M., Huss, M., Farinotti,D., Azisov E., Usubaliev,R., Gafurov, A., Petrakov,D., Kääb A., 2016. Mass-balance reconstruction for Glacier No. 354, Tien Shan, from 2003 to 2014. Ann. Glaciol. 57(71), 92-102, doi: 10.3189/2016AoG71A032.

45. Kumtor Gold Company, 2013. 2013 Environment and Sustainability Report. http://www.kumtor.kg/wp-content/uploads/2014/11/Eco2013_en.pdf. Last visited May 8, 2015.

46. Kutuzov S.S., 2012. Changes in glacier area and volume in Terskey Ala-Too Range in the second half of XX century. Ice and Snow 52(1), 5-14. doi:10.15356/2076-6734-20121-5-14 
47. Kutuzov S., Shahgedanova M., 2009. Glacier retreat and climatic variability in the eastern Terskey-Alatoo, inner Tien Shan between the middle of the 19th century and beginning of the 21st century. Glob. Planet. Chang. 69, 59-70.

48. Kuzmichenok V.A., 2012. Dust pollution of the atmosphere and glaciers in the area of Kumtor mineral deposit (Ak-Shyirak, Tien Shan). Ice and snow, 2(120), 131-140, (in Russian)

49. Kuzmichenok V.A., 1988. Fluctuations of Davydov and SaryTor glaciers from topographic surveys data. Data Glaciol. Stud. 62, 193-196 (in Russian).

50. Li, B., Zhu, A., Zhang, Y., Pei, T., Qin, C., Zhou, C., 2007 Glacier change over the past four decades in the middle Chinese Tien Shan. J. Glaciol. 52, 425-432.

51. Linsbauer, A., Paul F., Haeberli W., 2012. Modeling glacier thickness distribution and bed topography over entire mountain ranges with GlabTop: Application of a fast and robust approach. J. Geophys. Res. 117, P. F03007.

52. Linsbauer, A., Paul, F., Hoelzle, M., Frey, H., Haeberli, W., 2009. The Swiss Alps without glaciers — a GIS-based modelling approach for reconstruction of glacier beds. Proceedings of Geomorphometry 2009. Zurich, Switzerland, 243-247.

53. Liu C., Han T., 1992. Relation between recent glacier variations and climate in the Tien Shan mountains, central Asia. Ann. Glaciol. 16, 11-16.

54. Macheret, Y., Cherkasov, P.A., Bobrova, L.I., 1988. The thickness and volume of Dzhungarskiy Alatau glaciers from airborne radio echo-sounding data. Data Glaciol. Stud. 62, 59-70 (in Russian).

55. Macheret, Y., Kutuzov S., Matskovsky V., Lavrentiev, I., 2013. On ice volume estimation of mountain glaciers. Ice and Snow 1 (121), 5-15 (in Russian)

56. Mikhalenko VN., 1990. Usage of representative glacier for study of mass exchange in glacier systems. PhD Thesis, Moscow, 23 p. (in Russian) 
57. Minora U., Bocchiola D., D’Agata C., Maragno D., Mayer C., Lambrecht A., Mosconi B., Vuillermoz E., Senese A., Compostella C., Smiraglia C., Diolaiuti G., 2013. 20012010 glacier changes in the Central Karakoram National Park: a contribution to evaluate the magnitude and rate of the "Karakoram anomaly". Cryosphere Discuss., 7, 2891-2941, www.the-cryosphere-discuss.net/7/2891/2013/

58. Narama, C., Kääb, A., Duishonakulov M., Abdrakhmatov K., 2009. Spatial variability of recent glacier area changes in the Tien Shan Mountains, Central Asia, using Corona ( 1970), Landsat ( 2000), and ALOS ( 2007) satellite data. Glob. Planet. Chang. 71, 4254.

59. Narama, C., Shimamura, Y., Nakayama, D., Abdrakhmatov, K., 2006. Recent changes of glacier coverage in the western Terskey-Alatoo range, Kyrgyz Republic, using Corona and Landsat: Ann. Glaciol 43, 223-229.

60. Niederer, P., Bilenko, V., Ershove, N., Hurni, H., Yerokhin, S., Maselli, D., 2007. Tracing glacier wastage in the Northern Tien Shan (Kyrgyzstan/Central Asia) over the last 40 years. Clim. Chang. 86, 227-234. doi:10.1007/s10584-007-9288-6

61. Nye J.F., 1952. The mechanics of glacier flow. J.Glacio. 2, 82-93

62. O'Gorman, L. 1996. Subpixel precision of straight-edged shapes for registration and measurement, IEEE Transactions on Pattern Analysis and Machine Intelligence, 18, 746751, doi:10.1109/34.506796

63. Olyphant, G.A., 1986. Longwave radiation in mountainous areas and its influence on the energy balance of Alpine snowfields. Water Res. Res. 22, 62-66

64. Osmonov A, Bolch T, Xi C, Wei J and Kurban A, 2013. Glacier characteristics and changes in the Sary-Jaz River Basin (Central Tien Shan) 1990-2010. Remote Sens. Let. 4(8), 725-734 (doi:10.1080/2150704X.2013.789146)

65. Paul F, Barrand N E, Berthier E, Bolch T, Casey K, Frey H, Joshi S P, Konovalov V, Le Bris R, Moelg N, Nuth C, Pope A, Racoviteanu A, Rastner P, Raup B., Scharrer K, Steen 
S and Winswold S, 2013. On the accuracy of glacier outlines derived from remote sensing data. Ann. Glaciol. 54, 171-182.

66. Paul, F., Barry, R. G., Cogley, J. G., Frey, H., Haeberli, W., Ohmura, A., Ommanney, C. S. L., Raup, B., Rivera, A., and Zemp, M., 2010. Recommendations for the compilation of glacier inventory data from digital sources. Ann. Glaciol., 50 119-126

67. Paul, F and Kääb, A, 2005. Perspectives on the production of a glacier inventory from multispectral satellite data in Arctic Canada: Cumberland Peninsula, Baffin Island. Ann. Glaciol. 42, 59-66. doi: 10.3189/172756405781813087)

68. Paul, F., Kääb, A., Maisch, M., Kellenberger, T.W., Haeberli, W., 2002. The new remote sensing-derived Swiss glacier inventory: I. Methods. Ann. Glaciol. 34, 355-361.

69. Paul, F., Lindsbauer, A., 2012. Modeling of glacier bed topography from glacier outlines, central branch lines and a DEM. Int. J. of Geogr. Inf. Sci. http://dx.doi.org/10.1080/13658816.2011.627859.2012.

70. Petrakov, D.A., Kovalenko, N.V., Lavrentiev, I.I., Usubaliev, R.A., 2014. Ice thickness, volume and current changes of the Sary-Tor Glacier area (Ak-Shyirak massif, Inner TianShan). Earth's Cryosphere 18(3), 83-91.

71. Pfeffer, W.T., A.A. Arendt, A. Bliss, T. Bolch, J.G. Cogley, A.S. Gardner, J.O. Hagen, R. Hock, G. Kaser, C. Kienholz, E.S. Miles, G. Moholdt, N. Mölg, F. Paul, V. Radić, P. Rastner, B.H. Raup, J. Rich, M.J. Sharp and the Randolph Consortium, 2014. The Randolph Glacier Inventory: a globally complete inventory of glaciers, J. Glaciol. 60 (221), 537-551. doi:10.3189/2014JoG13J176.

72. Pieczonka T, Bolch T., 2015. Region-wide glacier mass budgets and area changes for the Central Tien Shan between 1975 and 1999 using Hexagon KH-9 imagery. Glob. Planet. Chang. 128, 1-13. doi:10.1016/j.gloplacha.2014.11.014. 
73. Pieczonka, T., Bolch, T., Junfeng, W., and Shiyin, L.., 2013. Heterogeneous mass loss of glaciers in the Aksu-Tarim Catchment (Central Tien Shan) revealed by 1976 KH-9 Hexagon and 2009 SPOT-5 stereo imagery. Remote Sens. Environ. 130, 233-244.

74. Radić V., Bliss A., Beedlow A. C., Hock R., Miles E., Cogley J. G., 2013. Regional and global projections of twenty-first century glacier mass changes in response to climate scenarios from global climate models. Clim. Dyn. doi:10.1007/s00382-013-1719-7.

75. Radic, V. and Hock, R., 2010. Regional and global volumes of glaciers derived from statistical upscaling of glacier inventory data. J. Geophys. Res., 115, F01010, doi:10.1029/2009JF001373.

76. Rankl, M., Vijay, S., Kienholz, C., Braun, M., 2013. Glacier changes in the Karakoram region mapped by multi-mission satellite imagery. Cryosphere Discuss., 7, 4065-4099. www.the-cryosphere-discuss.net/7/4065/2013/

77. Raup, B., Racoviteanu, A., Khals, S.J.S., Helm, C., Armstrong, R., Arnaud, Y., 2007. The GLIMS geospatial glacier database: a new tool for studying glacier change. Glob. Planet. Chang. 56, 101-110. doi:10.1016/j.gloplacha.2006.07.018.

78. Sorg A., Bolch T., Stoffel M., Solomina O., Beniston M., 2012. Climate change impacts on glaciers and runoff in Tien Shan (Central Asia). Nat. Clim. Chang. 2, 725-731

79. Sorg A., Huss M., Rohrer M., Stoffel M., 2014a. The days of plenty might soon be over in glacierized Central Asian catchments. Environ. Res. Lett. 9, 104018 (8pp), doi:10.1088/1748-9326/9/10/104018

80. Sorg, A., Mosello, B., Shalpykova, G., Allan, A., Hill, M., Stoffel, M., 2014b. Coping with changing water resources: The case of the Syr Darya river basin in Central Asia. Environ. Sci. Policy 43, 68-77.

81. Shangguan, D., Bolch, T., Ding, Y., Kröhnert, M., Pieczonka, T., Wetzel, H.-U., Liu, S., 2014. Elevation changes of Inylchek Glacier during 1974-2007, Central Tian Shan, Kyrgyzstan derived from remote sensing data. Cryosphere Discuss., 8, 2573-2610. 
82. Siegfried, T., Bernauer, T., Guiennet, R., Sellars, S., Robertson, A. W., Mankin, J., Bauer-Gottwein, P., and Yakovlev, A., 2012. Will climate change exacerbate water stress in Central Asia? Clim. Chang., 112, 881-899. doi:10.1007/s10584-011-0253-z.

83. Torgoev I.A., Aleshin J.G., 2001. Ekologia gornopromishlennovo kompleksa Kyrgyzstana. Ilim: Bishkek (in Russian).

84. Vasilenko Ye.V., Gromyko A.N., Dmitriev D.N., Macheret Yu.Ya. (1988). Structure of Davydov Glacier from radio-echo sounding data. Data Glaciol. Stud. 62, 208-215. (in Russian).

85. Vergara, W., Deeb, A., Valencia, A., Bradley, R., Francou, B., Zarzar, A.,Grünwaldt, A., and Haeussling, S., 2007. Economic Impact of rapid glacier retreat in the Andes. EOS 88(25), 261-262.

86. Wang S., Zhang M., Li Z., Wang F., Li H., Li Y., Huang X., 2011. Glacier area variation and climate change in the Chinese Tianshan Mountains since 1960. J. Geogr. Sci. 21, $263-273$.

87. Wang X., Siegert F., Zhou A., Franke J., 2013. Glacier and glacial lake changes and their relationship in the context of climate change, Central Tibetan Plateau 1972-2010. Glob. Planet. Chang. 111, 246-257.

88. Yao, T., Thompson, L.G., Yang, W., Yu,W., Gao, Y., Guol, X., Yang, X., Duan, K., Zhao, H., Xu, B., Pu, J., Lu, A., Xian, Y., Kattel, D.B., Joswiak, D., 2012. Different glacier status with atmospheric circulations in Tibetan Plateau and surroundings. Nat. Clim. Chang. 2, 663-667.

89. Zemp M., Hoelzle M., Haeberli W., 2009. Six decades of glacier mass-balance observations: a review of the worldwide monitoring network. Ann. Glaciol. 50, 101-111

90. Zemp M., van Woerden, J. (eds.). 2008. Global Glacier Changes: facts and figures. UNEP-WGMS, 88 p. 


\section{Figure captions}

Fig. 1. Ak-Shyirak massif in a panchromatic SPOT-5 image of 25 September 2013 with $2.5 \mathrm{~m}$ resolution. 1 - old Tien Shan weather station, 2 - new Tien Shan/Kumtor weather station, 3 - watershed between the main Naryn/Syr-Daria and Sary-Jaz/Aksu catchments, 4 - watersheds between secondary catchments, 5 - small catchments, 6 - name of the secondary catchment, a, b, ...f - location of glacier photos presented in Fig.2. Country codes on the location map (top left): CN—China, KG-Kyrgyzstan, KZ-Kazakhstan, TJ—Tajikistan, UZ-Uzbekistan. The panel (bottom left) show seasonal variations in monthly precipitation, $\mathrm{P}, \mathrm{mm}$, and monthly air temperature, T, ${ }^{\circ} \mathrm{C}$ for $1930-2014$ for the Tien Shan (1930-1996) and Tien Shan/Kumtor (19972014) weather stations.

Fig.2. Oblique photos of the Ak-Shyirak massif glaciation: a) valley glaciers in the Koyondy catchment; b) retreating snout of the Northern Karasay Glacier and cirque glaciers in Karasay catchment; c) accumulation area of the Northern Karasay Glacier; d) small glaciers at the southern slope of the Ak-Shyirak massif, Aktash catchment; e) valley glacier in the Kumtor catchment; f) Petrov Glacier, the largest in the Ak-Shyirak massif, with Petrov Lake in front of it. Helicopter and ground photos were taken by D. Petrakov during 2012-2014. The location of photos is shown in Fig.1.

Fig.3. Example of glacier outlines in the Koyandy catchment digitized in the a) SPOT-5 panchromatic image of 2013 (2,5 m/pixel); b) Terra ASTER image of 2003 (15 m/pixel). Blue glacier outlines are from 2013, red outlines are from 2003. 
Fig. 4. Distribution and change of Ak-Shyirak glacier parameters: a) distribution of glacier area by aspect during 2003 and 2013; b) change of glacier area by aspect during 2003-2013; c) distribution of glacier area by altitude in 2013; d) distribution of glacier area by slope angle in 2013.

Fig.5. Ak-Shyirak glacier-covered area change during 2003-2013. Inset in the top-left: relative glacier area changes for major catchments, \%. Inset in the bottom-right: glacier area changes for major catchments, sq.km; See also Table 1.

Fig.6 Comparison of medelled and measured ice thickness at Sary-Tor glacier: a) ice thickness pattern on obtained from GlabTop modeling, b) map of difference for measured and modeled ice thickness, c-f) cross-sections and longitudinal profile with measured and modeled ice thickness (c-f), names of profiles correspond to parts of the figure, e.g. c-c1 is shown in Fig 6cc.

Fig.7. Ice thickness pattern of the Ak-Shyirak massif glaciation in 2013 obtained from GlabTop modeling using: a) SRTM DEM and b) ASTER GDEM v.2; c) difference of ice thickness derived from a) and b) approaches, the hatched area shows coverage of the DEMs generated from QuickBird and GeoEye satellite images; d) comparison of glacier volumes derived from a) and b) approaches.

Fig.8. Series of warm season (May-September, or MJJAS) temperatures in 1930-2014 (blue line) and 7-year moving average (orange line), Tien Shan and Tien Shan-Kumtor weather stations. 
Fig.9. Technogenic impact on Ak-Shyirak glaciers. The Davydov Glacier snout in: a) 1971, declassified Corona satellite photograph; b) 2003, Terra ASTER image; c) 2006, SPOT-2 image; d) 2013, SPOT-5 image; e) main pit of Kumtor Gold Company in 2012. Photo by D.Petrakov. Due to the main pit (centre of the photo), the Davydov Glacier snout (right) is detached from the glacier headwaters (left). 


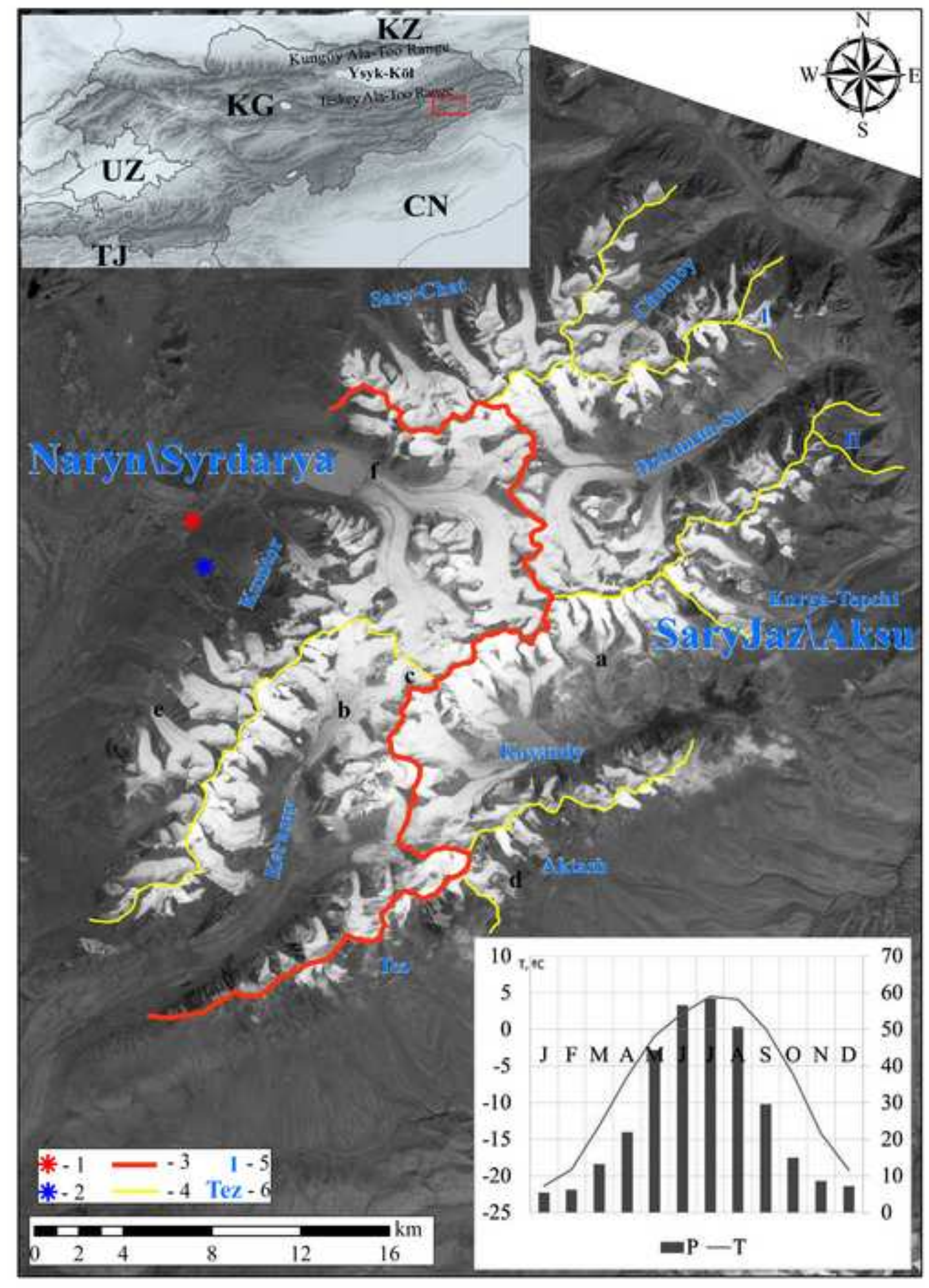




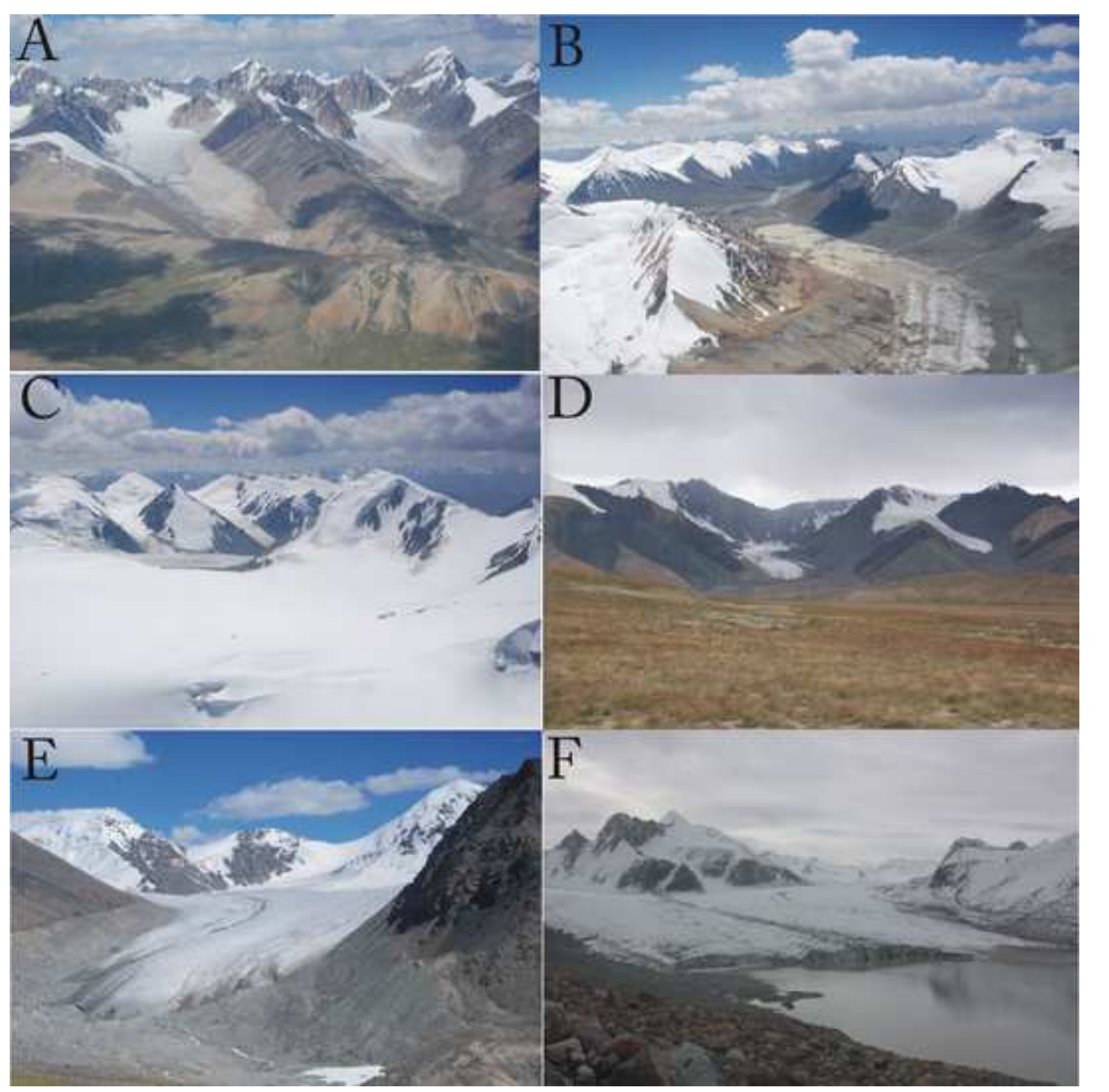

Figure 2

$A$
4
$C$

Figure

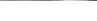



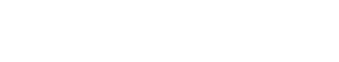

-

$$
\text { . }
$$$$
\text { . }
$$$$
\text { . }
$$$$
\text { . }
$$$$
\text { - }
$$

\title{
B
}
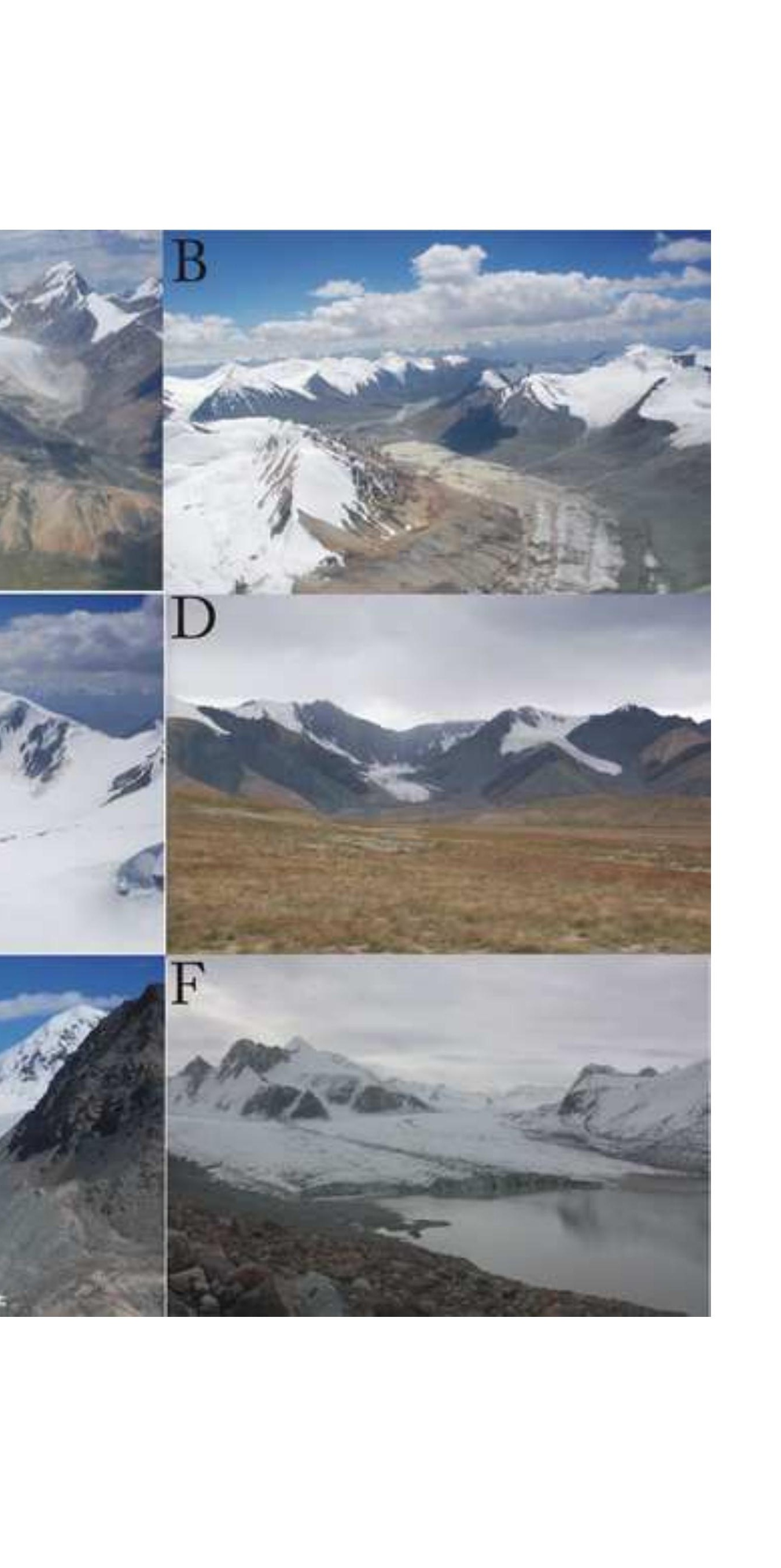

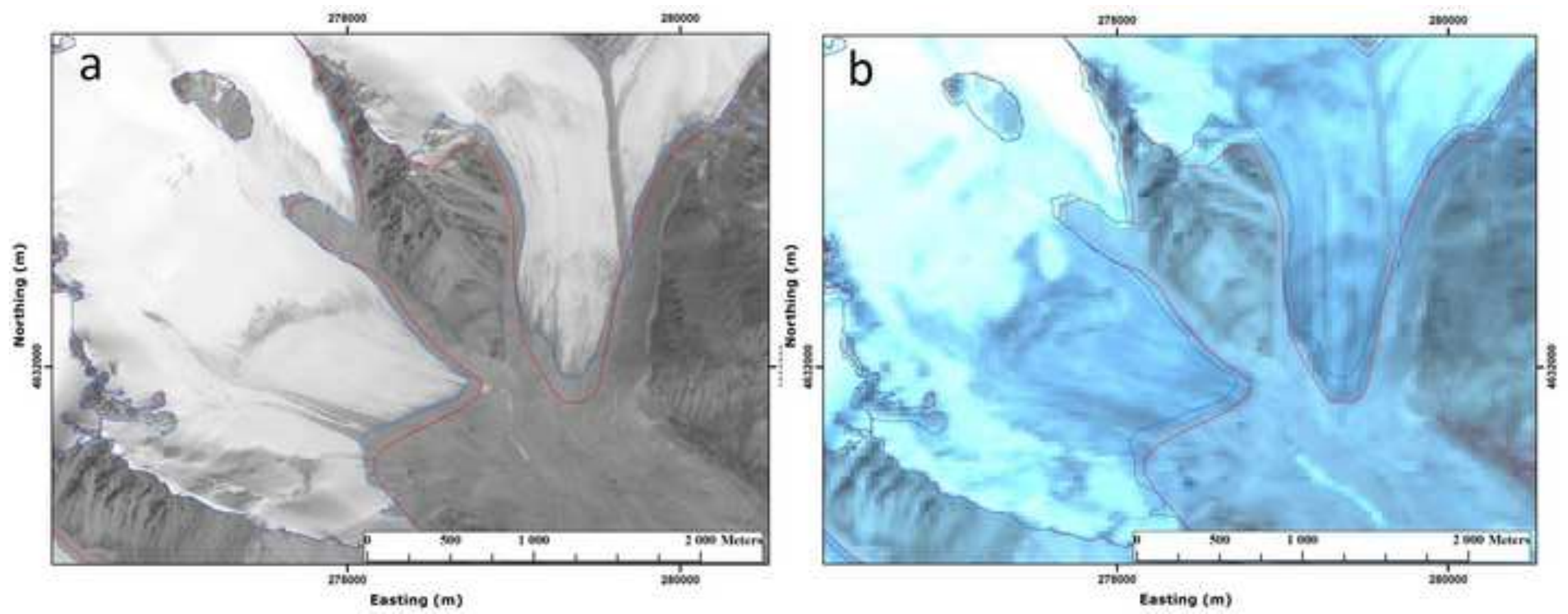

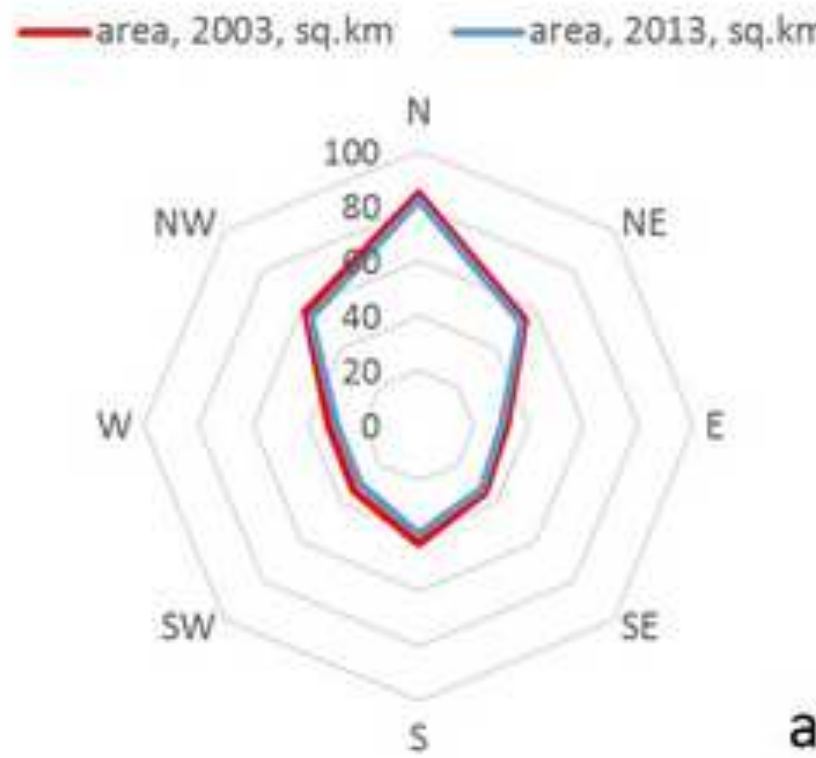

-area change, \% - area change, sq.km
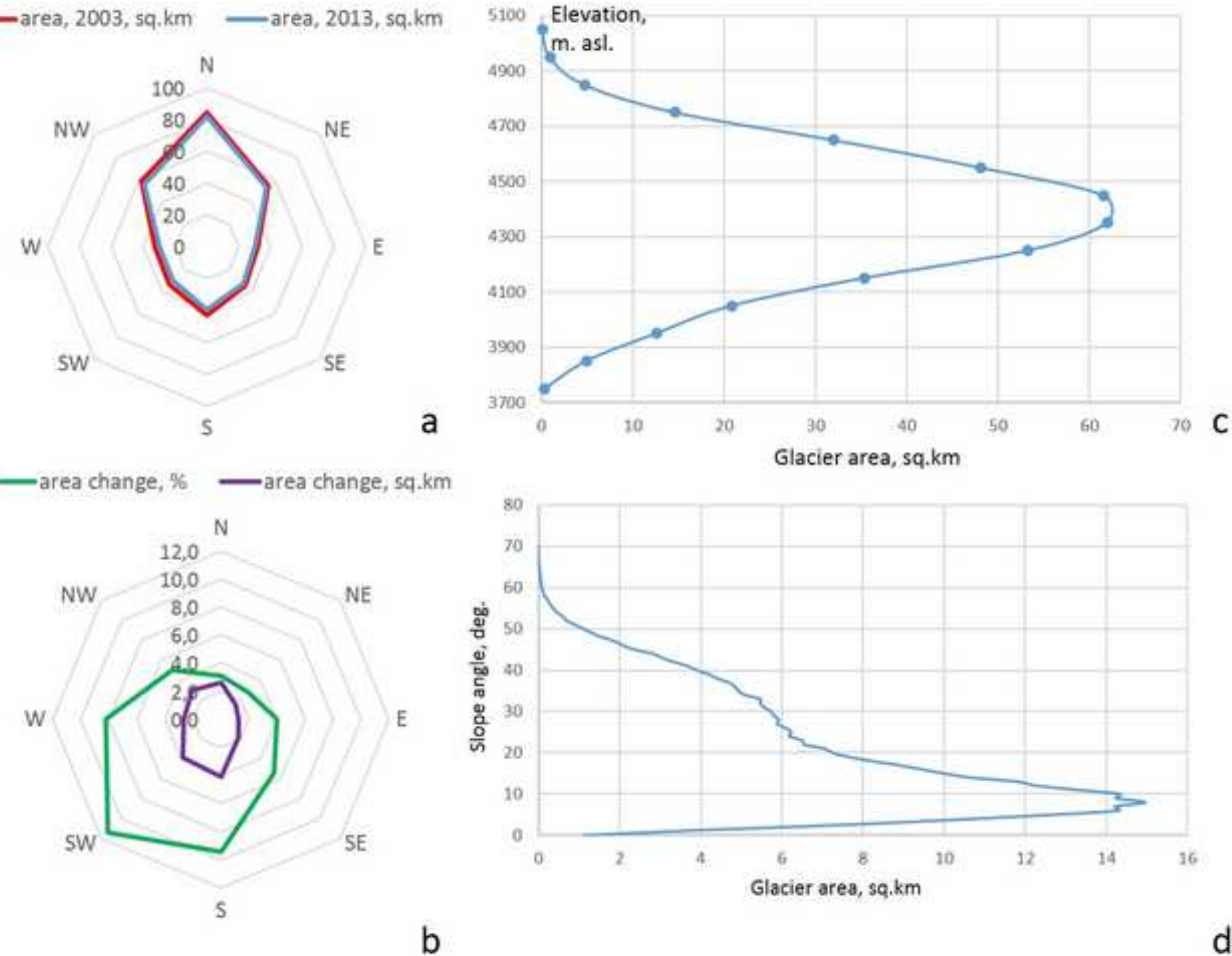

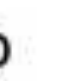




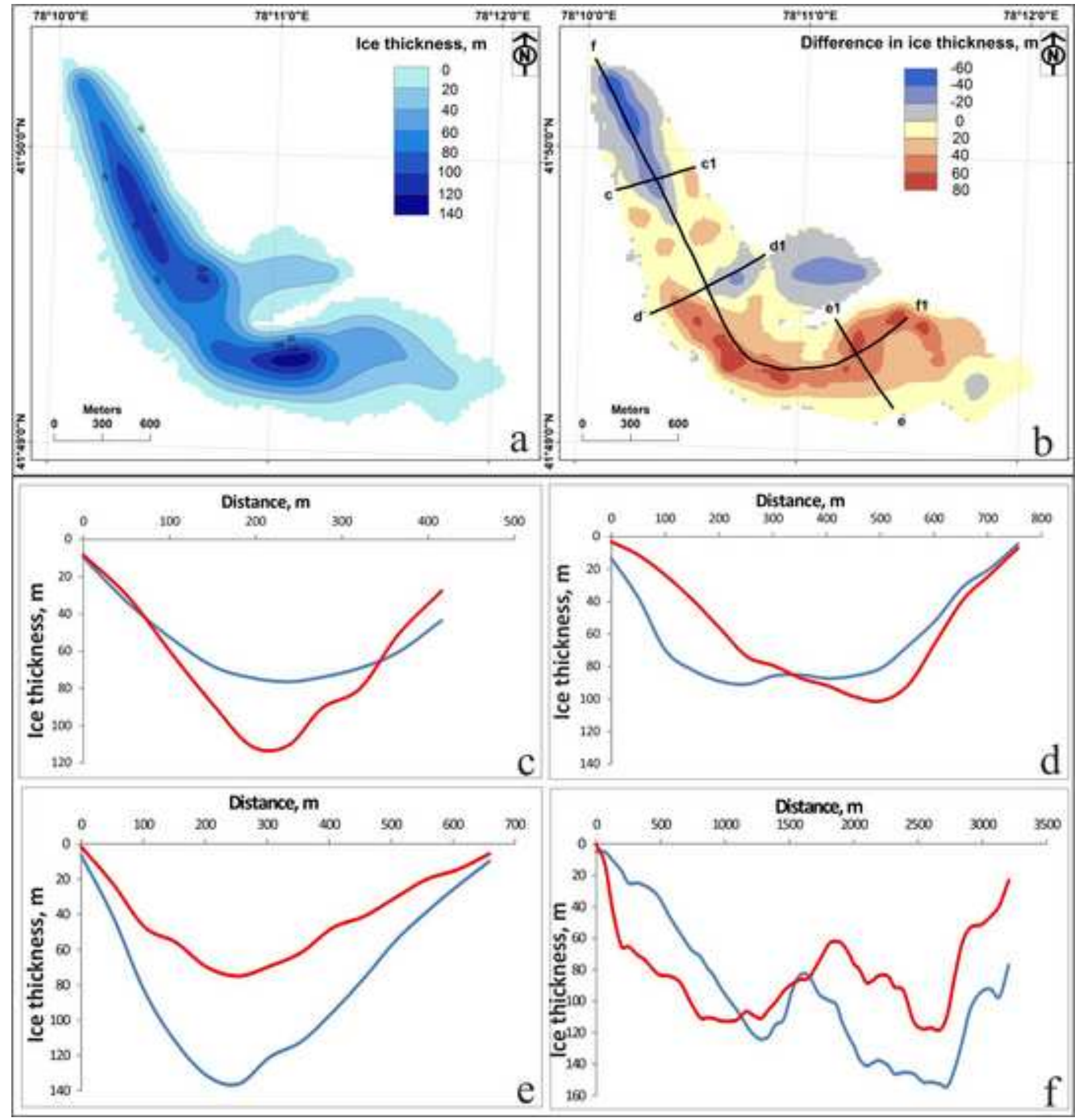



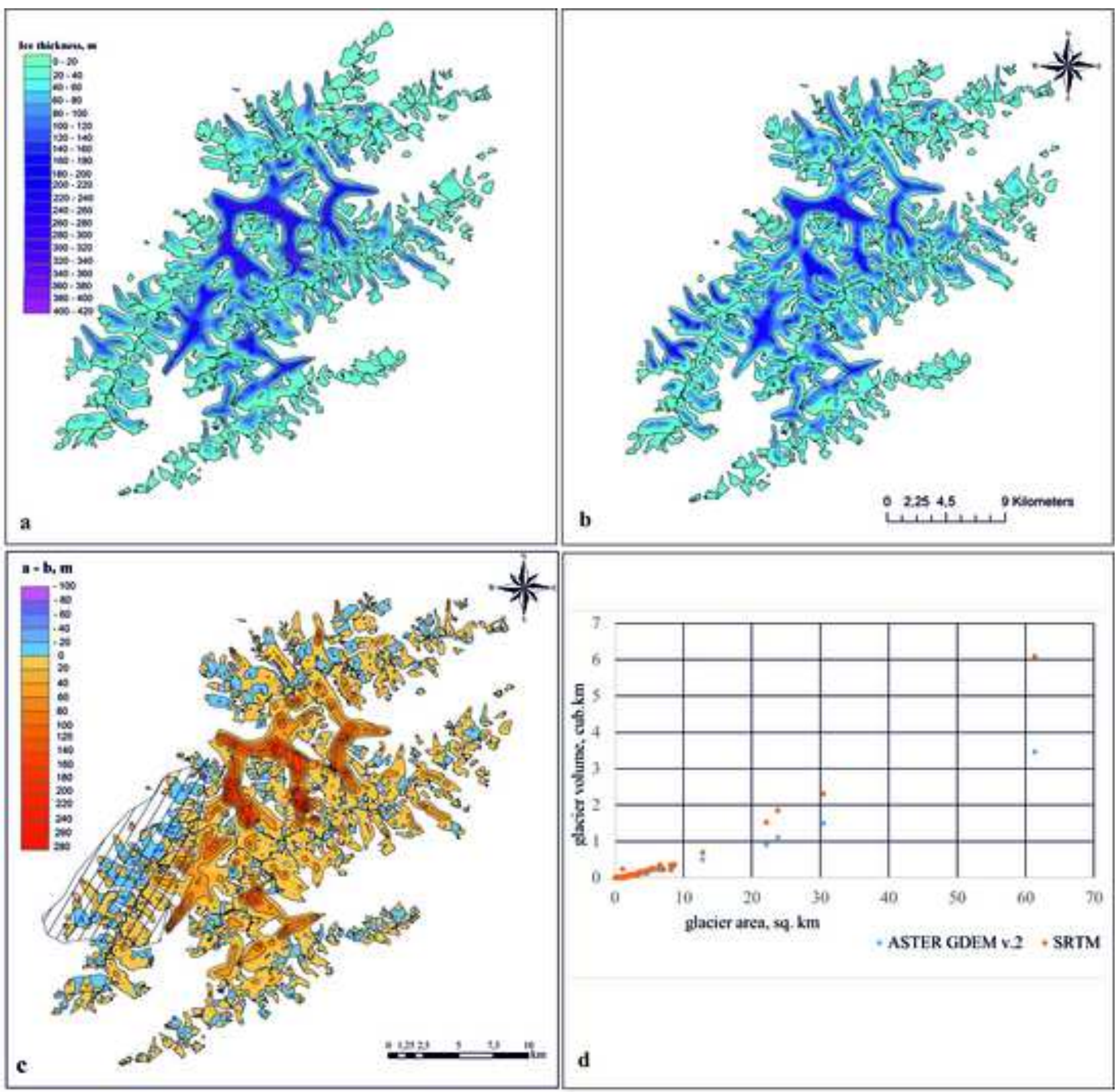


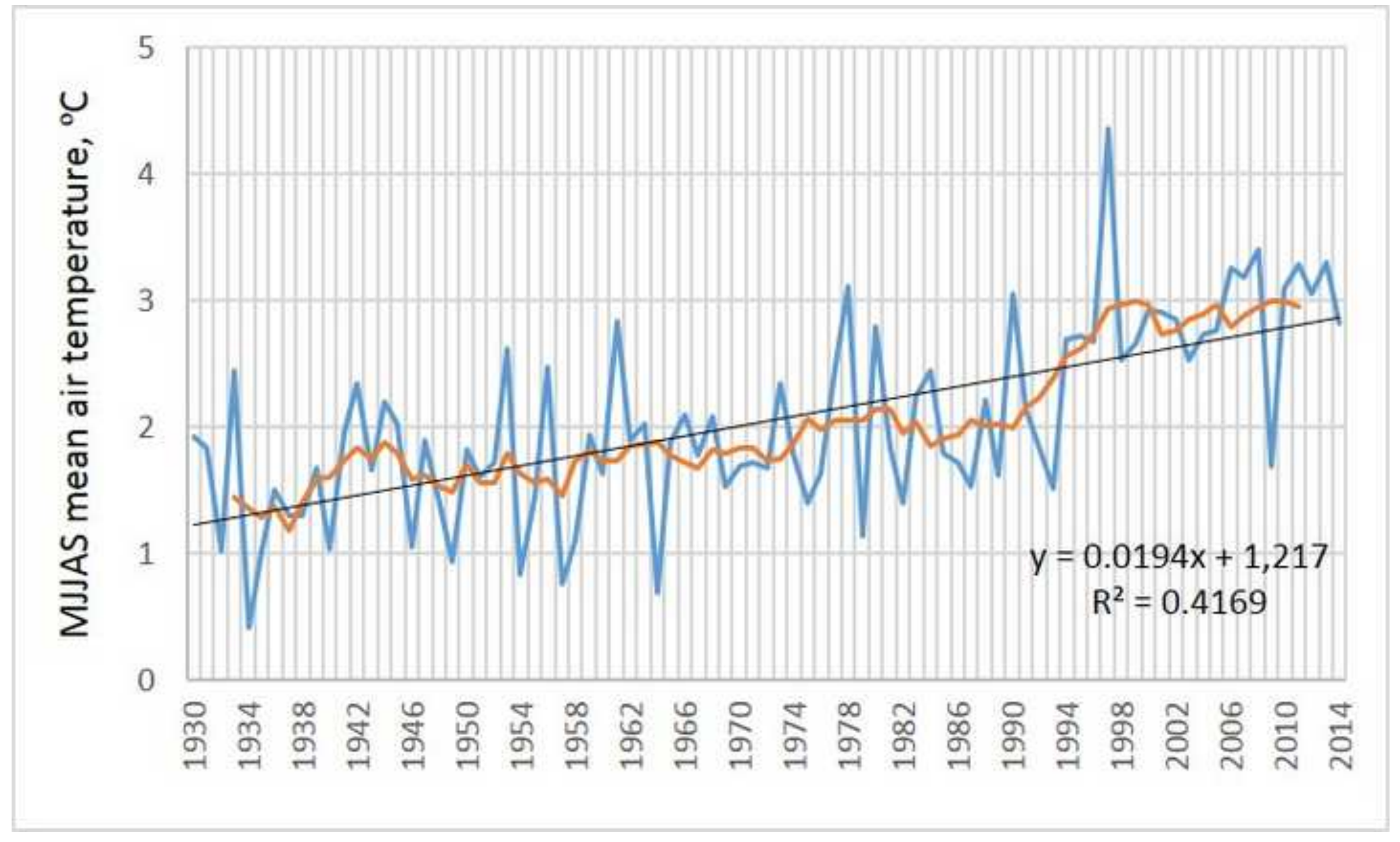



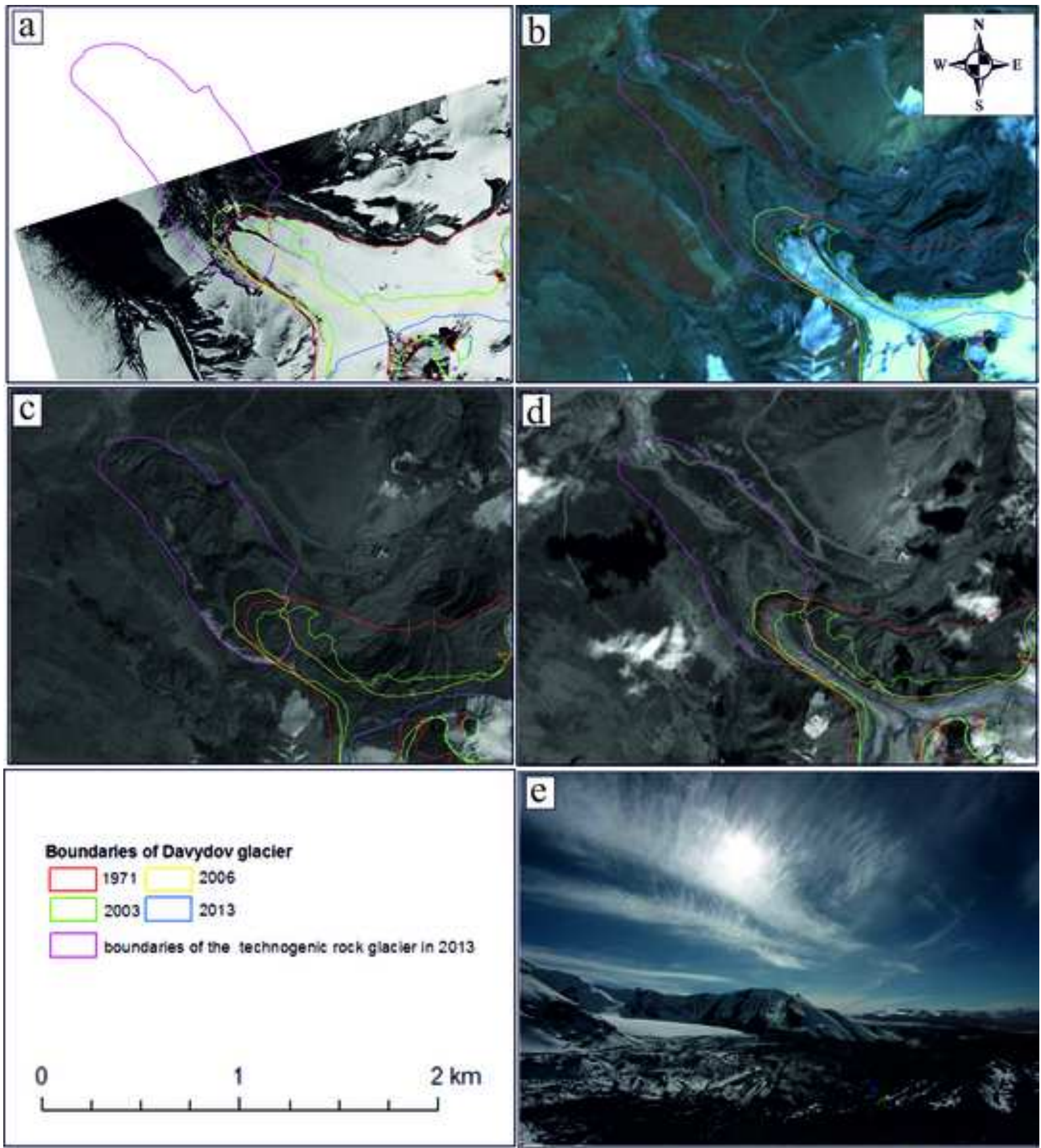

\section{e}

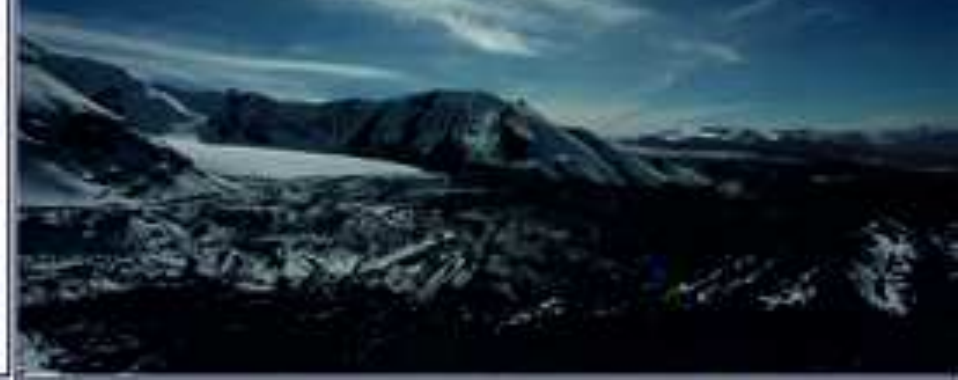

